\title{
EL CULTO K EN LA ERA CONTEMPORANEA: Crónica, génesis y apoteosis del proceso kirchnerista
}

\author{
Maximiliano E. Korstanje \\ Universidad de Palermo, Argentina
}

\begin{abstract}
Resumen: Desde el año 2003, con la asunción de N. Kirchner y posterior relevo de su mujer Cristina F. de Kirchner la Argentina ha experimentado una nueva razón para creer en la política pero a un costo muy alto. El trauma inicial que subsumió a la Argentina en grandes tasas de pobreza y desocupación consolidaron las bases para el nacimiento de un nuevo discurso político el cual en los últimos años se ha transformado en un Culto con todos sus elementos constitutivos. En este sentido, miedo político, dogmatismo, sufrimiento, grandeza, palabra, texto sagrado, arquetipo mítico, triunfo, debilidad, fortaleza y salvación son algunos de los componentes más representativos de la era política K. Desde una perspectiva objetiva, el presente ensayo explora las similitudes y diferencias entre el culto $\mathrm{K}$ y el fundamentalismo religioso en donde el pensamiento mágico no solo predomina sino impermeabiliza al colectivo con respecto al principio de realidad por medio de un proceso complejo donde convergen: negación, victimización y deshumanización.
\end{abstract}

Palabras clave: religiosidad, política, dogmatismo, Culto $\mathrm{K}$

Abstract.- Since 2003, the presidency of N. Kirchner and his wife Cristina F. de Kirchner in Argentina has given to society a reason to believe in the politics but at a higher risk. The initial trauma that subjugated the country during 2001 representing higher rates of poverty and unemployment has certainly paved the pathways for the advent of a new cult. As the previous argument given, the politic fear, dogmatism, suffering, greatness, word, sacred-text, victory, weakness, strength, and salvation are some of the most important indicators of the K-cult. From this perspective, this paper explores the similarities and differences with other religious fundamentalisms where the magical thinking not only predominates but also disconnects public opinion from the principle of reality. In doing so, the State elaborates a discourse as well as a much broader and complex process where negation, victimization and des-humanization converge.

Keywords: religiosity, politics, dogmatism, K. Cult

\section{Introducción}

En los últimos años la ciudadanía argentina ha sido testigo de un intento de imponer "interpretaciones políticas". Dichas interpretaciones, elaboradas sujetas incluso a tergiversaciones teóricas e históricas tales como "medios hegemónicos", "distribución de la riqueza", "división internacional del trabajo" y "polarización" etc, marcan una forma de hacer política que desconcierta a los analistas. Lejos de esbozar en este ensayo mi propia ideología política, estoy en condiciones de examinar (lo más objetivamente posible) en profundidad del discurso político de la Era $\mathrm{K}$ y como se ha construido una lógica del temor que amedrenta al electorado nacional. Si bien existe un gran consenso en académicos de segunda o tercera línea en discutir la influencia de los medios masivos de comunicación y los intereses corporativos, creemos la importancia de ese debate no reemplaza la urgencia de comprender como se ha construido el discurso del Culto K. El presente trabajo focaliza en la cultura del narcisismo tal como fue pensada por C. Lasch y en las contribuciones de autores como 
Ulrich Beck, Hanna Arendt, Corey Robin, Slavoj Zizek y Richard Bernstein en cuanto a la tergiversación política y las narrativas sociales. Las formas de construcción de lo político tanto del ex presidente Néstor Kirchner como de Cristina Fernández de Kirchner apelan a cuestiones fundamentales de un arquetipo mítico anclado en la década de los setenta en donde se vislumbra una mezcla de religiosidad y metodicidad argumentativa con un fuerte sesgo emocional (en ese ser-argentino) y estético que ciertos grupos de intelectuales (no humanistas) pero por sobre todo artistas y deportistas se esmeran por defender. La representatividad política de la argentina contemporánea, por último, no puede comprenderse sin aquello que el profesor Jose Luis de Imaz denominó Pigmentocracia, es decir, la idea de un orden económico establecido por medio del color de la piel y a la vez que se manifiesta en una imposibilidad cultural latinoamericano para concebir al otro y poder dialogar con él. Las turbulencias ocurridas desde 2003 hasta hoy no hacen más que legitimar la excepción de lo "menos peor". El electorado piensa, "nadie más que ..." puede continuar en el gobierno generando un círculo vicioso. Si como arguye Beck, el riesgo evita pero no ayuda a solucionar (oscureciendo el horizonte), los cursos de acción posibles, públicos, para solucionar los peligros se presentan como inocuos. El problema $\mathrm{K}$ es creado por los medios y para los medios.

\section{La Conquista de América y el Orden pigmentocrático}

Dos de los intelectuales que se han ocupado de estudiar las conceptualizaciones del bien y el mal (y su simbolización visual) desde la perspectiva socio-económica han sido el alemán Frederich Nietzsche y el estadounidense de origen noruego Thorstein Veblen. Es precisamente éste último quien advierte que las sociedades se dividen irreparablemente en clases. Si bien existen varias de ellas dentro de un grupo extenso, por lo general adquieren una tendencia bipolar a constituirse en dos principales: la productiva-técnica y la ociosa. Además, existe una vinculación directa de la producción económica con el paso de la historia; en los orígenes de la vida social nómada y sedentaria podemos observar una carencia de la emulación pecuniaria. A la clase ociosa pertenecen guerreros, sacerdotes, militares, deportistas e intelectuales entre otros. Su mentalidad puramente honoríficaestamental los lleva a valorar el mundo que los rodea en conceptos binomiales antagónicos como bueno y malo, alto y bajo, superior e inferior. Lo que subyace a ésta lógica nominal es un deseo agazapado de dominación subordinación con respecto al hombre técnico (Veblen, 1974). En algún punto, el arquetipo mítico asociado a la lucha entre bien y mal se ha materializado en cuestiones que hacen al color de piel.

El filólogo alemán F. Nietzsche sostenía que el principio genealógico de la moral (construido por medio de lo bueno y lo malo) no es otra cosa que un residuo aristocrático de las sociedades feudales enquistadas en el corazón de las religiones, sobre todo del cristianismo. El autor rastreaba etimológicamente el origen de las palabras "bueno" y "malo" encontrando similitudes en la mayoría de las lenguas indo-europeas. Lo bueno concepto utilizado para denotar valor, jerarquía hace referencia a un círculo de "caballeros nobles" mientras lo malo denotaba la simplicidad de la clase plebeya. En un afán de 
dominación territorial los grupos aristocráticos han creado por medio del lenguaje, mecanismo a su disposición para la creación y significados, realidades dispares en torno al concepto de bien y de mal. En efecto, fue en ese mismo proceso que la aristocracia compuesta por caballeros "rubios" encontró en Europa tribus autóctonas de cabellos oscuros como el caso de Britania e Italia. Desde ese entonces, la claridad pigmetocrática se ha convertido junto con las valoraciones morales en herramientas eficaces legitimadoras de la humillación y la expropiación impuesta por los invasores indo-arios. Fue el caso de los celtas y el vocablo fin-gal comúnmente asignado a la aristocracia estamental que significa "cabeza rubia" o latino Malus (asignado por los Italiotas ancestros de los romanos) término que significa "negro". Siguiendo esta misma explicación, en alemán la palabra schlecht (malo) simboliza "simple" o "vulgar" un vocablo originalmente utilizado peyorativamente para referirse al vulgo o pueblo llano sin distinción de nobleza (Nietzsche, 2007: 24). En concordancia con el argumento de Nietzsche, A. Giddens (1999: 285) afirma que el racismo y la discriminación hacia los "negros" tienen su origen en el génesis bíblico el cual establece que Dios crea el mundo relegando las "tinieblas" y trayendo la claridad de la vida de los hombres. Por ese motivo, no parece ser extraño que los europeos al llegar a África, por vez primera, vieran en "la oscuridad de sus pieles" un criterio negativo. Desde tiempos inmemoriales, los hombres parecen verse atraídos por la "claridad". El euro-centrismo basado en un criterio estéticopigmentocrático pronto se expandió por todo el planeta generando verdaderos lazos de subordinación entre los países centrales industrializados y los periféricos. ¿Podemos afirmar que la construcción de clase acorde al pigmento es un fenómeno religioso?.

La pigmentocracia puede ser definida como la institución jerárquica de un orden basado en el color de piel. J. $L$ de Imaz en su trabajo la identidad Iberoamericana argumenta convincentemente que la Conquista de América y la matriz cultural de España e Inglaterra han jugado un rol importante a la hora de concebir al otro y a las estructuras políticas. Si bien, Imaz advierte que ambas colonizaciones han sido llevadas a cabo en diferentes épocas, la conquista anglo-sajona ha partido de una necesidad de negociar las tierras con los grupos nativos. Eso fortaleció no solo la relación con su madre patria sino la negociación política como una forma de incluir a otro siempre étnicamente semejante. Los grupos originarios fueron excluidos de la nación blanca para formar parte de un imaginario subordinado. Por el contrario, si bien la colonización hispánica se consolidó gracias a un proceso de miscegenación (entre europeos y nativos) en donde los hijos representaban mayor volumen de brazos para el trabajo (principio feudal que ha permitido la formación de clases basadas en color de piel donde los blancos mantienen la hegemonía), la lógica bipolar (amigo-enemigo) de los militares españoles (quienes encabezaron la colonización a diferencia de Inglaterra) sentó las bases para una conflictiva relación con la madre patria, con las otras colonias (hecho observable en la cantidad de guerras entre estados una vez independizados y revoluciones civiles) e imposibilitó a las naciones emergentes para comprender la "otreidad". De esa manera, la independencia de los Estados latinoamericanos fue marcada por el conflicto, la desigualdad y la exclusión de la disidencia (Imaz, 1984). Las contribuciones de Imaz fueron retomadas por Korstanje quien afirma 
que la matriz cultural hispánica, ligada al latinismo Romano donde la ciudadanía era adscripta, mientras el germano antiguo daba la pertenencia por asociación étnica. De tal forma, la base de la colonización hispánica, similar a la roma y la inglesa propia de la germánica originaron dos formas de hacer política (Korstanje, 2010). Empero a diferencia de lo que asume el etnocentrismo anglo (Huntington, 1993) bajo la tesis que los países latinoamericanos son menos democráticos que los anglosajones, Korstanje sugiere que existen diferentes formas de concebir la democracia. Mientras los anglosajones priorizan la función de sus instituciones para solucionar las fallas y los errores, los latinoamericanos anteponen como prioridad la solución del problema en lugar de la funcionalidad de la institución (de idéntica forma que el Imperio Romano). En otras palabras, los ciudadanos en Estados Unidos consideran que el congreso debe arreglar las situaciones generadas por el ejecutivo lo cual le da más sustentabilidad en el tiempo al sistema pero lo hace más hegemónico y autoritario para con terceros países, mientras en Latinoamérica, se considera necesaria la "intervención" de grupos ajenos al sistema político generando mayor inestabilidad y falta de credibilidad en las instituciones democráticas pero con mayor inclusión hacia terceros países. Si para los anglos la legitimidad (étnica) es por sobre la eficacia, para los latinos la eficacia debe exceder (por cuestión del bien común) a la legitimidad (Korstanje, 2007, 2010b). J. L. de Imaz no se equivoca cuando afirma los militares sudamericanos, se han equivocadamente puesto en el rol de ser los "salvadores de la Patria" y han recurrido a los golpes de Estado como una forma correctiva en el momento en que consideraban la nación estaba en peligro (Imaz, 1964). Eso no implica que Canadá y Estados Unidos no tuvieran intentos de golpes militares, sino que los han resuelto por medio del "soborno" y la "negociación". Luego han devenido la inmigración europea, la oligarquía paternalista agraria, la división y el proyecto nacional que finalmente confronta en 1945 el choque entre un ruralismo autoritario y criollo contra un europeismo urbano y progresista de las grandes ciudades (Agulla, 1986) (Panettieri, 1970) (Potash, 1986) (Lieuwen, 1960). Por su parte, como sugiere C. Agulla explica, el problema (clivaje) argentino ha sido siempre la imposibilidad de poder organizar dos tipos de Argentinas, la profunda (rural y tradicional orientada al pasado) y la urbana (que mira al progreso y al futuro que inspira Europa) (Agulla, 1986) y claro A. Jauretche, un ensayista político con una gran sensibilidad social es el primero en mezclar el principio de la pigmentocracia hispánica con serios problemas de método y una historia (elaborada) sin ningún tipo de respaldo de fuentes históricas. De esta forma, Jauretche metió en la misma bolsa a Rivadavia, San Martín, Sarmiento, el Imperio Británico, un supuesto sentimiento de anglo-filia, los ferrocarriles, Perón, el movimiento industrial, el campo agrario y el psicoanálisis freudiano (por medio del síndrome de inferioridad). Claro es el problema de como Jauretche no era historiador construye un relato histórico-fantástico que sirve de sustento ideológico para generaciones enteras. La complejidad de la historia argentina es erróneamente resumida para Jauretche en un claro binomio: amor por lo autóctono vs. Autodesprecio y admiración por lo europeo (veremos más adelante que misma lógica subyace en la necesidad de rescatar los textos de W. Benjamín por parte de Forster o de la Escuela de Frankfurt en Feinmann) 
La adopción de una doctrina marxista equivocada terminó por confundir a gran mayoría de la intelingentsia argentina. Cuando Marx elabora el Capital, explica el profesor Fillipi, no está pensando en ninguna revolución social, sino en Inglaterra. Marx de ninguna manera pretende que los pueblos (del tercer mundo) mejoren su situación, sino como científico su objetivo es crear una ley de la historia y admitir la dominación como componente importante de la misma. Esa ley nacida de la lucha de clases, y una mala interpretación del darwinismo biológico, condiciona los estados de evolución de las sociedades. Cuando las bases productivas están en condiciones de chocar con las fuerzas de producción. En este estadio de maduración del capital, se estará admite Marx en condiciones de iniciar la "última revolución" y el "fin de la historia". Marx nunca aclara cuales son los indicadores ciertos para ese estadio pero si está claro que la revolución solo puede ser posible en un país industrial, nunca en un país agrario. Como la historia se mueve gracias a la lucha de clases, Marx ve con buenos ojos la política expansionista en Estados Unidos con respecto México hasta el punto que en 1848 desde Nueva York apoya la invasión americana. Lo que Marx pretendía era vivir para ver probada su teoría del fin de la lucha de clases, y nada mejor que para eso apoyar la causa de los países industrializados. México no tendría ninguna oportunidad frente al industrial Estados Unidos. Por algún motivo, en Latinoamérica los intelectuales no adoptaron la tesis de Marx sino la de Lenin que justificaba la revolución de los países agrarios. Ello conllevó a una serie de indefiniciones y ajustes simbólicos para adoptar al marxismo como teoría social de las clases intelectuales argentinas y por supuesto latinoamericanas (Fillipi, 1988). Para finalizar la sección, tenemos una situación de rivalidad no definida entre las ciudades y el campo, una pigmetocracia que hiere la susceptibilidad de los grupos, y un estadio de desigualdad en crecimiento que solo resulta en una urbanización creciente e imparable. Este proceso favorece la especulación histórica del suelo y problemas habitacionales importantes que afianzan la discriminación social desde México a la Argentina.

\section{Riesgo y la Invención de lo Político en U. Beck}

Beck sugiere que la forma de trabajo se debería considerar en torno al y. Si en el siglo XIX, la especialización laboral estaba regida por el o, uno era alfarero o carpintero, en la actualidad, la fórmula cambia a alfarero y carpintero. "La vaguedad del y" como es definida por Beck, es un ejemplo de la cosmovisión actual del mundo, sus deseos de unicidad, su falta de límites, el caos y el ascenso de las incertidumbres y miedos que aquejan a la sociedad. La caída en el mundo del "o-bien-o" está condicionada a dos hechos internacionales tales como el accidente de Chernobyl y la caída del muro de Berlín. La amenaza nace como producto de la indeterminación, la enajenación y la expropiación de las seguridades del sujeto (nuevamente vemos la preocupación por la autenticidad). La sociedad moderna se diferencia de la industrial por el advenimiento de una lógica reflexiva la cual permite una mayor información y divulgación pero a la vez mayor temor. La invención de lo político, entonces, no solo genera reglas sino que las altera llevando a la política de ser una concepción de poder a un "arte de lo político" en manos de la sociedad. La era del "y" es de una gran ambivalencia en donde la ecología 
rescata los valores organizados de aquellos quienes todavía no han nacido. Es decir, de aquellos que no tienen representación cierta frente a un estado. Al postulado, todos los valores morales de la modernidad se disuelven, Beck agrega, la ecología es el último de los reductos morales.

El concepto de sociedad de riesgo puede ser comprendido en base a tres dimensiones. La primera se refiere a la conexión a la sociedad industrial con los recursos ambientales ya sea naturaleza y cultura de cuyo lazo se nutre pero cuyas reservas erosiona constantemente para mantenerse. Segundo, existe una relación incuestionable entre la sociedad y los peligros creados por ella misma. El riesgo apela a la intervención política. Tercero, la "destrucción de las fuentes de pensamiento colectivo" lleva a un proceso de individuación en donde el sujeto es puesto fuera de la sociedad industrial en completa turbulencia. Donde falla la seguridad "prometida" nace la sociedad del riesgo, admite Beck. Este postulado el autor lo explica de la siguiente forma; las inseguridades han sido un problema desde antaño para las diferentes culturas y grupos humanos. Sin embargo, los modernos consideran al peligro como sujeto a la resolución de una lógica instrumental (decisión). El creciente proceso de secularización y la desacralización de la política han confluido para poner al hombre en el plano de las decisiones. Las promesas de seguridad promovidas por el Estado, caen en una situación paradojal. Por un lado legitiman la autoridad del Estado, por medio de las normas establecidas, a la vez que erosionan su sustentabilidad. Los riesgos son negados cuando amenazan al principio auto-construido de controlabilidad. Lo político puede ser definido, en este contexto, como la negación de los peligros reales por medio de la transformación de normas que llevan a un principio de asegurabilidad (el seguro es la expresión primera de este fenómeno) pero que dadas ciertas condiciones origina su propio estado de desastre. En otras palabras, Beck pone un ejemplo claro: el estado de desarrollo pensado para el siglo XX que ha llevado a las sociedades occidentales a resolver muchas de sus inseguridades, empero por medio del efecto invernadero, destruir la predictivilidad y eficiencia de las compañías internacionales de seguro frente a los grandes huracanes y desastres ecológicos como inundaciones etc.

La tesis central de Beck es que la sociedad se hace reflexiva en cuanto a que tematiza sobre ella misma como tema, y como problema. En palabras del propio autor, "de la toma de consciencia de los peligros dependientes de decisiones surge lo político, pues las relaciones de propiedad, las desigualdades sociales y los principios de funcionamiento de la sociedad industrial permanecen en su totalidad, sin ser afectados por ella. En este sentido, la teoría de la sociedad del riesgo es una teoría del conocimiento político de la modernidad progresivamente auto-crítica. Se Trata de la cuestión de qué y cómo la sociedad industrial se ve, se critica y se transforma como sociedad de riesgo" (Beck, 1998: 50). La organización política nace del accidente, pero no del accidente como tal sino de la normalización del mismo, no obstante, existen peligros que dependen de la sociedad y otros que escapan a ella. La política no corrige los peligros ya que es producto y no productora en la sociedad del riesgo. Empero ¿Cuál es el tratamiento que Beck hace de lo nacional?. 
Las naciones son para Beck comunidades imaginadas, limitadas en donde aún quienes no se conocen se imaginan dentro de una pertenencia común. En este lugar de pertenencia la palabra y el consumo de periódicos se transforman en los rituales más extendidos de cohesión entre los ciudadanos. En consecuencia, los medios masivos de comunicación son funcionales a la formación del Estado-Nación. Esta construcción es una sustitución del derecho divino (Beck, 1998: 104). Existe una relación entre milicia, democracia y Estado. Todas las democracias occidentales son democracias militarizadas en donde la hipótesis del enemigo da sustento a su razón de ser. Beck, en este punto esboza 7 presupuestos que pueden resumirse de la siguiente forma: 1) todas las democracias hacen una simbiosis entre sus fuerzas armadas y el sistema democrático, 2) los enemigos persisten el paso de la historia, 3) el concepto de Estado determina una cuestión bipolar de derecha-izquierda, 4) la intimidación nuclear ha tenido un efecto amenazante, 5) el Estado se alimenta de la autoridad y gracias a ella construye su noción de soberanía, 6) los estados son posibles por medio de la construcción de una incertidumbre constante que permite intervenciones, y 7) las necesidades que dan origen a la milicia son balanceadas "con contra necesidades de democracia". Entre milicia y democracia no solo hay una interrelación mutua sino además una justificación de mutuo "asedio". En palabras de Beck, las democracias son todas "militarmente restringidas" a la amenaza externa/interna (Beck, p. 110). Desde esta perspectiva, existirían dos tipos de autoridades, las que emanan del pueblo y la que deriva del enemigo. Si se parte de la base que un enemigo genera el concepto de seguridad y entonces crea comunidad pero a diferencia de los criminales (conocidos por el Estado y condenados según mi derecho) los enemigos tienen su derecho a disposición. Todo consenso en cuanto a defensa habla de un poder subyacente. Pero ¿que pasa cuando el enemigo externo se hace interno?. Para responder a esa pregunta es necesario adentrarse en las profundidades del miedo político y sus alcances no solo en las dictaduras sino en los regimenes democráticos.

\section{Laclau y la Razón del Populismo}

La democracia representa un problema para los sistemas capitalistas. Si bien por un lado, ella abre las fronteras a derecho del comercio, por el otro cierra las mismas a desplazamientos de personas "no deseadas" por imposición de la ley. C. Mouffe propone un modelo político que se aleje de pensar las cosas en términos de buenas o malas como los actuales. Recientemente, la teoría política parece haber cambiado de rumbo por cuanto los modelos agregativos en los cuales la democracia era considerada una sumatoria de intereses individuales se encuentran en declive. En su lugar ha surgido la idea de "democracia deliberativa" cuyos principios apuntan a que "las cuestiones políticas son de naturaleza moral $y$, por consiguiente susceptibles de tratamiento racional. El objetivo de una sociedad democrática, es, desde esa perspectiva, la creación de un consenso racional alcanzado por medio de procedimientos deliberativos apropiados cuya finalidad es la de generar decisiones que representen un punto de vista imparcial, en interés de todos por igual' (Mouffe, 2005: 79). 
La autora sugiere que ese modelo racionalista lleva a no comprender las verdaderas cuestiones de la arena política. Teóricos de la política como Rawls, Dworking y Rorty fallan a la hora de explicar las implicancias reales de lo político en la vida del hombre. Es paradójico, tal vez escribe Mouffe observar como uno de sus máximos enemigos $\mathrm{C}$. Schmitt diga más sobre la democracia, la norma y la política que los propios liberales. Con este argumento en mente, la politóloga se predispone a rescatar las consideraciones schmittianas sobre lógica amigo/enemigo y la tesis del decisionismo. Las sociedades humanas basan su solidaridad y su política gracias a la hostilidad; pero lo cierto es que Schmitt nunca pensó superar las limitaciones liberales sobre la democracia sino simplemente anular la democracia. En este punto, se diferencian los tratamientos de Schmitt con el anhelo de Mouffe. La tesis de Mouffe apunta a que la identidad de los grupos humanos se forja gracias a la intervención de un "ellos" o de un "exterior constitutivo" que ayuda a subrayar las diferencias entre los grupos que a su vez son construidas por medio de la jerarquización social. Cuando los hombres perciben a los "otros" como amenazadores a sus propios valores responden con hostilidad. La dimensión antagónica es, pues, "lo político" mientras "la política" refiere a todas las prácticas encauzadas con el fin de crear un orden cosmogónico (fundador). En consecuencia, el motor que mueve los hilos de la democracia, como régimen político, es la pasión para la creación de identidad. En este contexto, Mouffe presenta su tesis del "pluralismo agonístico" que no es otra cosa que "un intento de domesticar la hostilidad" derribando el mito del consenso social a cualquier costo. Los otros en la democracia deben ser vistos como adversarios y no como enemigos.

Por su parte, Ernesto Laclau analiza el rol del populismo en las actuales demandas de la ciudadanía. Según el scholar, el prerrequisito para los sistemas populistas es que gran parte de las demandas sociales en seguridad, bienestar, empleo y distribución de la riqueza entre otras hayan quedado insatisfechas. En la demanda, quien envía la petición reconoce en el receptor el poder en la solución a su problemática. Laclau sostiene que cuanto las demandas tienden a ser absorbidas en forma diferencial, más débiles se tornan los vínculos "equivalenciales" y menor la probabilidad de constituir un espíritu popular. A la inversa, la cantidad de demandas igualmente insatisfechas predisponen institucionalmente para el "populismo". En otras palabras, cada demanda es rica en sí misma y representa la punta de un iceberg; la homogenización de todas ellas sólo es posible bajo el vaciamiento de sus sentidos. Precisamente, el populismo no solo antagoniza con un enemigo visible sino que también condensa todas las demandas en el nombre del líder (Laclau, 2005: 35).

La tesis central de Laclau puede ser reconstruida en las siguientes partes: a) todo sistema institucional experimenta un declive en la medida en que no puede absorber en forma diferenciada las demandas sociales y recurre a cadenas de equivalentes antagónicas, como por ejemplo las reivindicaciones de Derecha e Izquierda sobre determinada problemática social como puede ser el desempleo o la demanda de seguridad. Ambas posturas toman "la misma equivalente flotante" pero presentan estrategias diferentes, b) en la medida que el estado instituye una lógica preferencial, la identidad popular "se torna cada vez más inoperante", c) la ideología se instituye como el requisito para la 
creación discursiva de homogeneidad propia del populismo. Ello significa que "un movimiento o una ideología - o, para colocar a ambos bajo su género común, un discurso- será más o menos populista dependiendo del grado en que sus contenidos estén articulados por lógicas equivalenciales. Esto significa que ningún movimiento político estará enteramente exento de populismo, porque ninguno dejará de interpelar en alguna medida al pueblo contra un enemigo" (lbíd. 44).

De esta lectura, Laclau se desprende la idea que el populismo no es corruptor de la política sino su elemento fundante por el cual se tejen la hegemonía y su discurso. En este sentido, todos los pueblos acuden a sus propios sentidos de representación distorsionando su sentido de identidad. Esta consecuencia inmediata es ineludible a la estructuración de cualquier sistema político. Las contribuciones del profesor Laclau al estudio de la legitimidad y la eficacia radica en comprender que la función última de la hegemonía y el populismo será quebrar las fronteras internas construidas por los grupos de poder antagónicos al gobierno de turno, en la medida en que mayores fronteras se construyan menor será el mensaje del populismo pero también la eficacia en cuestiones de gobernabilidad. Por el contrario, cuantas menores barreras existan dentro del sistema social la demanda será efectivamente satisfecha pero peligrosamente unívoca.

\section{Nociones y Principios de la Religión}

La palabra religión viene del latín religare, que significa "atar". Su función es precisamente ligar a la pertenencia del hombre a un objeto (de culto). S. Freud enfatizaba en la religión como un mecanismo psicológico de proyección la cual ayuda a resolver la neurosis del trauma inicial. El monoteísmo judío era para el padre del psicoanálisis la resultante de un conflicto entre el culto egipcio de akhenatón y Amón-Ra (Freud, 2004). Este trauma inicial puede ser interpretado en términos de $\mathrm{F}$. de Coulanges como el miedo a la muerte. De esta forma, explica el historiador francés la religión de los antiguos nace a través del fuego sagrado y la necesidad de ser protegido por los ancestros una vez en el más allá (Coulanges, 2005) o por medio de la frustración según Feuerbach (2009); para éste último, los dioses y la religión se corresponden con una proyección equilibrante de los hombres por la cual nivelan sus propias frustraciones. El proceso de antropormofización se explica así: si los hombres son mortales, limitados en su conocimiento y sujetos a error, los dioses son inmortales, ilimitados, omniscientes, y todopoderosos. La religión es a Feuerbach el principio de auto-reflexión humana (Feuerbach, 2009).

Luego de lo expuesto, podemos definir a la religión como "cualquier creencia que encierra la aceptación de lo sagrado en un mundo que excede lo empírico vinculando al hombre con su medio y sus privaciones" (Connolly, 2006: 6). Existen diferentes formas de vivir lo sagrado según la siguiente tipología. Lo personal-sagrado hace referencia a los asuntos familiares vinculados a la trascendencia, por ejemplo los antepasados que son únicos de cada clan. Luego viene lo espiritual sagrado que se comprende como una idea colectiva de trascendencia que une a los hombres en tiempo y espacio (con tradiciones y 
mismo territorio en común). Lo sagrado-civil es una resultante del proceso de nacionalización de lo sagrado cuya máxima expresión es la bandera y los signos patrios. Por último, tenemos una idea totalizadora de la cosmovisión que puede ser entendida como lo religioso-sagrado (Evans, 2003). En forma cíclica, asume Durkheim, la existencia de símbolos patrios es la resultante del proceso de secularización moderno. El amor por la patria ha reemplazado a la antigua religión aunque sus dinámicas persisten (Durkheim, 1992). La forma esencial de la religión es el poder, o la búsqueda de poder radical (Lorenzini, 2006). La concepción de divinidad se antepone por un acto de violencia por el cual el estado sustituiría a la religión (Balandier, 2004).

Pero es lo ¿religioso un proceso político o precisamente es el culto una deformación de lo religioso?. E. Gellner afirma "Malinowski explained religion and science in terms of his functionalist theory of human needs. In a late work, he listed seven spheres within which society must satisfy basic human needs: metabolism, reproduction, bodily comforts, safety, movement, growth, and health. Religion, he argued, served to provide psychological support in the face of death. He thought that Durkheim's theory was overdone, but he admitted that religion also often served to bind a community together" (Gellner, 2006: 17). En este sentido, la religión se pregunta precisamente por las últimas de las cuestiones que angustian a la humanidad, la trascendencia cuya naturaleza es universal. El hombre, al ser el único animal dotado de la abstracción para figurarse su propia muerte, necesita de un principio explicatorio que preserve su razón de ser (Blackmore, 2000). Este apoyo psíquico, como afirma Gellner, es una respuesta al principio de muerte. Por el contrario, el culto es la politización del principio de trascendencia que expropiada de la religión toma forma concreta en un territorio e historia común. Esta unicidad requerida es posible gracias a los elementos que provee la religión tales como doctrina, experiencia, ritual, y mito (Smart, 1998: 591). Diferentes analistas han concertado que a diferencia de la religión, la religiosidad popular hace del conflicto entre dominadores y dominados su discurso principal. La mayoría de los caudillos populares, a los cuales se rinde culto, han estado fuera de la ley por defender a los más débiles y fueron asesinados muy jóvenes por el poder económico y político.

La sacralización de los muertos junto al conflicto dan lugar a la devoción popular la cual en parte es rechazada o aceptada por la Iglesia oficial (en el caso de Latinoamérica la Católica Apostólica Romana) (Delgado, 1993) (Seman, 2001) (Carozzi, 2005). En tal sentido, Soneira define a la religiosidad popular como toda práctica, acto, conducta o sentimiento masivo que funciona como estructura mediadora entre la matriz sagrada y los grupos humanos en forma paralela en algunos casos o enfrentada en otros, a las prácticas del sistema religioso oficial. Si bien la naturaleza de los elementos que hacen a esta religiosidad difieren con respecto a cada contexto social, existen cinco de ellos que son comunes a todas estas prácticas: la sacralización de los muertos, la idea de conflicto o lucha social de las clases menos privilegiadas, el sincretismo, ciertas fechas de conmemoración bien definidas, y la promesa como elemento relacional entre lo sagrado y el grupo humano. Llegado a este punto de análisis cabe repreguntarse, ¿es la religiosidad causa de 
conflicto?. Una bella descripción a cargo de Norbert Elías nos ayudará a comprender el problema.

Centrado en el caso de Winston Parva, un pueblo inglés, Elías sugiere que el conflicto comienza no solo con el proceso de territorialización (y no de la diferencia sustentada como pensaba Jaurteche y los pseudo intelectuales) sino también por la construcción de ideología. En Winston Parva coexistían dos grupos de obreros de baja calificación: unos llamados "viejas familias" las cuales discriminaban a un segundo grupo denominados las "nuevas familias". Estos dos grupos antagónicos eran idénticamente iguales en cuanto a su composición étnica y de clase pero los distanciaba la antigüedad de residencia en el pueblo. Los estereotipos negativos asumen la inferioridad del grupo "nuevo" y la superioridad moral del grupo viejo. No basta con pertenecer al grupo "viejo" sino de merecer esa pertenencia. El rumor y el prejuicio son dos mecanismos sociales de control que las viejas familias utilizan para crear hegemonía en las nuevas, es decir, hacer creer "que realmente son inferiores". El cima de inseguridad, asociado a un proceso más amplio de "victimización" funda las bases para la creación del culto. La estigmatización y el sacrificio (de las víctimas) permiten una expiación como muestra viva de superioridad (Elías, 1998). De esa forma, las victimas se transforman en victimarios. En este punto, la religión no es por sí misma factor de discordia, pero se considera la raíz de la política por medio de la cual los hombres construyen la narrativa cosmogónica que les da sustento a sus prácticas (ancladas en la producción económica) y a sus creencias sobre la causalidad de un mundo impersonal (Aronoff, 1984) (Berger, 1971) (Comaroff y Comaroff, 1999) (Horowitz, 1984) (Wolf, 2004) (Lukes, 2005).

\section{La espera del Mesías (Slavoj Zizek)}

El mundo moderno se ha caracterizado por una pérdida gradual de los poderes eclesiásticos sobre el mundo social, pero es falso afirmar que la religión ha desaparecido, como bien observa S. Zizek en su capítulo introductorio de la obra El Titere y el Enano. Entonces, la religión puede desempeñar dos funciones antagónicas según Zizek: una terapéutica que ayude a los hombres a vivir mejor y la otra crítica que rompa los círculos y discursos hegemónicos que sintetizan todo lo malo de un orden específico. A la religión del pueblo propia de los "antiguos", siempre ligada a las costumbres culturales de una sociedad, se le suma la religión positiva definida como el conjunto de reglas a respetarse por el simple hecho de haber sido dadas por la divinidad (incuestionable).

En nuestros días la religión debe ser admitida dentro del seno privado como "un obsceno secreto". Al respecto escribe Zizek "lo que quiero declarar aquí no es meramente que soy un materialista por donde se me mire y que el núcleo subversivo del cristianismo también es accesible a un enfoque materialista. Mi tesis es mucho más tajante: sostengo que este núcleo sólo es accesible desde un punto de vista materialista y, viceversa, para llegar a ser un auténtico materialista dialéctico, uno debería pasar por la experiencia cristiana (Zizek, 2005: 14). La modernidad ha aceptado a las religiones y a las creencias bajo el signo de las comillas; ello no significa que no creamos sino todo lo contrario, 
que creemos "más que nunca". Cuando escribimos o leemos un texto, las comillas nos marcan la posición subjetiva del autor de la cual debemos dudar, sin este mecanismo ortográfico creeríamos sin cuestionamientos previos en lo escrito. Lo escrito y la palabra dan mayor credibilidad al discurso.

El cristianismo, y sobre todo el cristianismo de Pablo han marcado una abrupta ruptura entre el Jesús histórico y el Cristo resucitado. Empero, en Occidente la tendencia parece apuntar a un desplazamiento de las creencias o de los sistemas religiosos hacia otras instituciones como la cultura. En efecto, los ritos religiosos se conservan aún no como símbolo de fe sino como herencia cultural. Cuando los talibanes cortaron las cabezas de las estatuas de Buda, las sociedades occidentales protestaron enérgicamente no porqué creyeran en Buda, sino por considerar ese actor un atentado "a la cultura". La tesis de Zizek es que la imagen de Cristo simboliza la reconversión del Dios-Dios al DiosHombre. Pero, el cristianismo posee un núcleo "oculto" y perverso que subvierte el orden de los valores religiosos no sólo ya como una "doctrina terriblemente revolucionaria" sino además como la única religión que promueve la traición como forma de redención. En las mayorías de los cultos Dios le pide a sus fieles que se mantengan leales a Él, pero en el cristianismo Jesús necesita de la traición y aún sabiéndolo deja los hechos tomen su curso. La posibilidad, cita Zizek a Chesterton (1997), de que un hombre bueno se encuentre entre la espada y la pared es algo bien sabido pero que el mismo Dios hecho hombre se encuentre en esa situación, parece algo diferente. Más en el último momento luego de haber atravesado todo el calvario, Jesús se permite dudar de Dios. Si para las religiones del mundo, Dios muere cuando los hombres se apartan de él, en el cristianismo Dios muere para sí.

Lo cierto parece ser que el Cristianismo ha sobrevivido como estructura e institución a varios regimenes políticos como el feudalismo, la burguesía, el socialismo y el capitalismo. La pregunta central es ¿cómo y porque?. Centrado en la doctrina del goce condicionado de Hegel (1992), Zizek admite que el Cristianismo ha sido un corpus de ideas que ha fomentado que una persona puede vivir en un castillo de cristal con la felicidad dentro del bolsillo siempre y cuando no transgreda determinada norma. $Y$ si lo hace, hay otro mundo en donde uno puede acceder a la felicidad eterna. Esta limitación que en apariencia se presenta como arbitraria nos recuerda el acceso limitado a la felicidad y enfatiza en la presencia del don divino como aquel que ha permitido dicho acceso. De esta forma toda carencia emocional y material no sólo como criticaba Nietzsche es regulada por medio de la promesa y la esperanza de un mundo "mejor" sino que también explica la posición del otro en el condicionamiento del goce.

En palabras del propio Zizek "en el sentido estrictamente lacaniano de los términos, uno debería pues postular que la felicidad se basa en la incapacidad o la disposición del sujeto para confrontar plenamente las consecuencias de su deseo: el precio de la felicidad es que el sujeto permanezca fijado a la inconsistencia de su deseo" (p. 63). Lo perverso de este juego es que los actores que demandan cambios pueden mantener inalterable su fachada sabiendo que sus peticiones jamás serán cumplidas (si la riqueza es producto de la pobreza, como entender la redistribución de la riqueza?, no es acaso la 
expansión de la pobreza?). La posición anti-utópica de Zizek es respaldada por el ejemplo de los académicos "progresistas" quienes cínicamente promueven la libertad de derechos para los inmigrantes y los más débiles pero que saben que sus pedidos no serán oídos, y más se alegran por ello. Si los "reciénllegados" accedieran espontáneamente a los privilegios y beneficios de los nativos eso generaría un choque con la clase dominante (entre ellos los académicos). Esta brillante observación apunta a que por fuera el erudito profesa una igualdad que en su interior rechaza enérgicamente.

A diario los temas de investigación que proponen los intelectuales para sus ensayos versan sobre temas que apuntan la pobreza, la marginalidad y la inmigración encabezan el ranking de carencias. En raras ocasiones, los trabajos apuntan a las clases "privilegiadas" de las cuales los mismos intelectuales forman parte. Zizek pone el ejemplo de la relación política entre Estados Unidos y Cuba con respecto a la migración. Frente a una nueva oleada de migrantes, en 1994 Cuba advirtió a Estados Unidos que iba a suprimir la ilegalidad de emigrar, sí éste último no dejaba de promover la inmigración de cubanos. Pronto, ante la amenaza de una migración masiva los Estados Unidos accedieron a la petición cubana. En este sentido, el ego es descubierto en su fachada precisamente por el riesgo que el alter vea satisfecha su demanda amenazando así la posición privilegiada. La imposibilidad de la demanda garantiza la estabilidad del sistema. Empero, Zizek redobla la apuesta, y en su desarrollo, arremete contra el mensaje del cristianismo el cual, lejos del sacrificio, incita al fiel a abandonarse a sus propios deseos. Cristo en su crucifixión ha cargado con "los pecados" de todos los mortales, pero los sigue cargando en cada "confesión". El mensaje de este rito es "puedes entregarte a tus deseos y gozar, iyo cargo el precio sobre mis espaldas!" (p. 71). Este funcionamiento "perverso" evoca a la religión que da al goce cierta legitimidad y lo aparta de los deberes morales para que el fiel vida su momento con impunidad. Uno de los mayores enigmas tanto dentro del cristianismo como del judaísmo es la figura del sufrimiento y el sentido que éste toma para el fiel. De esta forma, tanto Job quien es sometido a innumerables penurias sólo por capricho de Dios y un alarde de poder como Cristo quien en última instancia exclama "¿Padre porque me has abandonado?, se encuentran emparentados en el sinsentido del sufrimiento humano, sufrimiento siempre del más débil. Uno por exceso de poder, el otro por impotencia.

Ahora bien, existen ciertas diferencias en como ambos relatos construyen la omnipotencia de Dios. El Dios de Job, a pesar de su crueldad, es una entidad omnipotente, misteriosa cuya máxima crítica es mantenerse ajeno al sufrimiento de Job mientras que el Dios de Cristo se transforma una entidad amorosa, bondadosa pero impotente al sufrimiento de su propio hijo. En otras palabras, Job hace responsable directamente a Dios por sus infortunios mientras que Cristo lo hace indirectamente responsable "a su Padre" por la pasividad ante el dolor. En este punto de análisis, Zizek sugiere que ambos relatos tienen una significación complementaria, Job no solo demuestra la imposibilidad de Dios para cambiar el curso del sufrimiento sino también el presagio de la pasión de su propio hijo, "hoy me toca a mí y mañana será el turno de tu propio hijo y no habrá nadie que interceda por él" (p. 173). Finalmente, Zizek focaliza su trabajo en el rol que la angustia juega en ambas 
religiones. Escribe textualmente "de acuerdo con Rozenzweig, la diferencia entre los creyentes judíos y los creyentes cristianos no estriba en que los últimos no experimentan angustia, sino en que han desplazado el foco de la angustia: los cristianos experimentan la angustia en la intimidad de su contacto con Dios (¿Cómo Abraham?), mientras que para los judíos, la angustia surge de su condición de miembros de una entidad colectiva sin un país propio, amenazada en su existencia" (ibid. 177).

El cristianismo representa la sustracción de la identidad judía en sí misma al la vez que la relación de la humanidad con Cristo se da como el efecto de un sueño en donde la cosa no reemplaza al signo sino que deviene signo en sí misma. Metafóricamente hablando, si mientras duermo, me duele el pecho, el sueño brinda al sujeto una fantasía y una narrativa para explicar el dolor. El cristianismo, a diferencia del judaísmo, ya ha consumado la aparición de su Mesías, en tanto que los cristianos quienes han experimentado las consecuencias del "gran acontecimiento" se lanzan activamente a la conquista del orden universal. No es que "Dios propone, el hombre dispone" (p. 187).... agrega Zizek, sino que Dios dispone y después el hombre propone. Al igual que el signo de la predestinación que nos conduce a un movimiento incesante para demostrar ser parte de la elección, el cristianismo también obliga al hombre a mejorarse diariamente (progreso). Si la gran venida ya ha sido sublimada, sólo la superación personal puede, en cierta instancia, garantizar la propia posición con respecto a las frustraciones de la vida. La religión al igual que el cinismo político preservan la legitimidad del más fuerte por medio del discurso de la protección del más débil por medio del advenimiento de un Mesías, y claro está el kirchnerismo parece no ser la excepción. Cuando Julio Cobos, presidente del Senado, vota en contra de la resolución 125 que enfrenta el gobierno de Cristina F. de Kirchner al movimiento ruralista, el Senador M. A. Pichetto utiliza las palabras de Cristo a Judas en la última cena, lo que debas hacer hazlo ya!. La traición de Cobos, Redrado, etc ha sido utilitariamente funcional a la construcción de un culto político. Recuerdo ese período incuso cuando el ex presidente N. Kirchner afirmaba que si la res. 125 se derogaba los ciudadanos experimentarían un retroceso económico sin precedentes, he aquí un elemento importante de todo culto, el temor. La posibilidad de retornar a un pasado traumático donde priman los sufrimientos y la desolación (como fue Diciembre de 2001) permiten alimentar "el miedo político" como arma de disuasión y persuasión que culminan con la famosa "militancia" o (conversión). Esta clase de conversión se lleva a cabo gracias a una reducción drástica en el sentido de critica y por sobre todo una infravaloración del propio self: "Señor no soy digno que entres en mi casa pero una palabra tuya bastará para sanarlo".

\section{El Miedo Político}

Beck afirma que vivimos en un momento en donde la modernidad reflexiva ha modificado sustancialmente el sentido de todas las instituciones pero ha dejado intacta la fachada. De igual forma, vivimos la lógica del "como si" hasta el punto de simular un escenario cuando en el fondo las reglas que dieron origen a ese escenario ya no aplican. La familia, la Iglesia, la religión incluso la forma de 
hacer política que caracterizaron a la forma de sociedad industrial han mutado a algo nuevo que define al riesgo como su principal eje fundante (Beck, 2006). ¿Es el miedo político fundador del orden social como sostenía Thomas Hobbes?. El Premio novel de literatura W Soyinka confirma que el miedo es funcional al poder pero no lo constituye como tal. En su naturaleza de autosuficiencia el poder emplea al miedo como una metodología para subsistir. Desde esta perspectiva, el poder no debe comprender como un mediador de fines políticos sino como una volición por dominar al-otro quitándole su libertad. El hombre se debate entre el miedo a ser controlado y el propio ejercicio de la libertad. Partiendo de la idea que el poder es una "mutación mortal" de la ambición, cualquier grupo o persona puede transformarse en agente de poder. El poder entonces se convierte en el "pantanal" primordial del miedo del cual nace nuestra neurótica aversión a la muerte (Soyinka, 2007).

Por su parte, M. Foucault sostiene que el poder político se erige gracias al principio de seguridad. Las sociedades consideran su seguridad interna en base a la buena fortuna y a los criterios de escasez que de ella se desprenden. En efecto, la escasez debe comprenderse como un estado de impotencia que cualquier Estado quiere evitar. A la interpretación que la sociedad hace de la contingencia, Foucault la llama problema del acontecimiento. La penuria que provoca cualquier alza de precios debido a la escasez está asociada a la autopercepción de que tal estado se ha debido a una falta por parte de la humanidad, ya sea por excesiva ambición o credulidad. Entendida, entonces, la escasez como parte de la "mala suerte" y ésta última de la "mala índole humana", existe alrededor todo un sistema jurídico y disciplinario con el fin de amortiguar los efectos de la escasez en la población: el control de precios. Foucault distingue, de todos modos, el principio disciplinario de la seguridad. El primero aplica sobre el desvío a la norma jurídica mientras el segundo regula de antemano los factores que infieren en la seguridad interna. En otras palabras, la seguridad tiende a lidiar con la continencia de las decisiones en materia de organización. Asimismo el concepto de seguridad comprende también al disciplinario y legal. El adoctrinamiento de los individuos en sociedad da lugar a la población como un concepto más complejo destinado a formar parte de un sistema holístico de oferta y demanda. Según Foucault, una mala cosecha puede despertar hambre, una suba generalizada en el precio del grano en un país determinado, no obstante, sabiendo de esa situación los países circundantes especularán sobre cual es el momento oportuno (según sus propios intereses) para venderles granos. Como ellos no saben cual será la estrategia de otros proveedores se lanzarán compulsivamente a vender granos e indefectiblemente bajarán los precios. En este contexto, la población (idea de pueblo) nace como resultado del accionar de la disciplina del Estado y el respeto por la ley, pero por sobre todo, de la obediencia colectiva. No existe seguridad sin territorio como así tampoco poder sin súbditos. Si la disciplina fija la estrategia, la seguridad hace lo propio con el caso, el riesgo y la crisis. La función de la seguridad es crear dentro de la sociedad el consenso necesario para aceptar la situación dentro de ciertos límites que llevan a aislar la peligrosidad. Ello es precisamente, lo que el autor llama "normalización disciplinaria" la cual consiste en crear un modelo con el cual se identifican los miembros de cierto grupo (Foucault, 2006). El sentido auto-dirigido de crisis es de capital importancia no solo para comprender el origen de lo político, sino 
justificar la ley y las reglas de intervención sobre las personas y el territorio (principio administrado de gobierno). Ahora bien cabe preguntarse ¿cual es la función del miedo político en la construcción hegemónica?.

El miedo político ha sido un concepto examinado por casi más de dos milenios que lleva de existencia la filosofía (sino más remontándose a los presocráticos). Desde Aristóteles hasta Hobbes pasando por las más variadas perspectivas como Montesquieu o Tocqueville, todos han visto en el miedo una variable importante de la vida social y política de un Estado o ciudad. En este sentido, el libro de C. Robin intenta resumir, analizar y explicar el papel del miedo -tanto interno como externo- como posibilidad de renovación pero también como instrumento de adoctrinamiento interno. El miedo, como lo imaginamos, conduce voluntariamente al sujeto a la apacible tranquilidad de la vida pero lo obliga a renunciar a ciertas actitudes de resistencia (pasividad). En su trabajo titulado El Miedo, Robin intenta reconstruir el mito judeo-cristiano de Adán y Eva. Dios descubre que luego de comer del árbol prohibido, ambos tenían miedo y se esconden. Antes del pecado, el hombre caminaba libremente por el jardín del Edén hasta que el rigor del trabajo esclaviza sus cuerpos y sus mentes. En consecuencia, la imposición ético-moral trae consigo consecuencias indeseables, el miedo. El autor elabora una análoga comparación de la situación de Adán con respecto a los atentados del 11 de Septiembre de 2001 en donde miles de estadounidenses salieron forzosamente del letargo cultural en el cual se encontraban. La sociedad americana había estado sujeta a diversos miedos asociados a la Guerra Fría o las revueltas raciales, más desconocían su responsabilidad directa en la conformación del problema. Todo miedo es principalmente político pues su interés radica en la dominación.

El miedo se construye, de esta forma, como una base o trampolín hacia la dominación de las controversias subyacentes antes del momento crucial que ha despertado a la sociedad. Ese momento mítico es reinterpretado siguiendo una lógica bipolar de amigo/enemigo y genera la movilización de recursos humanos o materiales con fines específicos. En los enemigos, por regla general, se depositan una serie de estereotipos con el fin de disminuir su autoestima y masculinidad. Demonizados no tanto por lo que han hecho sino por sus conductas sexuales, atribuimos a ellos grandes desordenes psicológicos. La incorregibilidad de estas anomalías conlleva a la idea de confrontación y posterior exterminio. El miedo como sentimiento primario subpolítico debe ser comprendido en tanto resultado de las creencias se encuentra vinculado con la ansiedad. En este contexto, Robin sugiere que el miedo político no debe entenderse como un mecanismo "salvador del yo" sino un instrumento de "elite" para gobernar las resistencias dadas del campo social. Éste, a su vez, posee dos subtipos: interno y externo. El miedo externo se construye con el fin de mantener a la comunidad unida frente a un "mal" 0 "peligro" que se presenta ajeno a la misma. En otros términos, esta amenaza atenta contra el bienestar de la población en general. Por el contrario, el segundo tipo surge de las incongruencias nacidas en el seno de las jerarquías sociales. Cada grupo humano posee diferenciales de poder producto de las relaciones que los distinguen y le dan identidad. La tendencia a identificarse con una cultura o una nación se corresponde con la negación de la sociedad 
política. Los intelectuales ansiosos identifican a las sociedades civiles como la base sobre la cual debería edificarse las relaciones sociales. Iglesias, universidades y ONGs asumen un papel de protagonismo en la configuración de la sociedad; el la política tradicional los electores ven corrupción y maximalismo utilitarista. El liberalismo ansioso busca un "yo más fuerte" que no logra encontrar, aumento así su decepción y frustración (Robin, 2009)

Por todos los puntos expuestos podemos afirmar que en una época, cuyo eje discursivo, se cierne alrededor de las estrategias de gobierno con respecto a la seguridad de la población, el presente texto se constituye como una obra de valor imponderable como así también una cita obligada para todos aquellos quienes quieran desarrollar el tema. El único problema que puede observarse en su construcción es que Foucault no imagina como funciona el Estado postmoderno. O por lo menos, no concibe todavía la desintegración del Estado moderno como hoy la experimentamos. Este hecho sumado a una imagen autorreflexiva de sí y de sus gobernantes (característica insoslayable de la postmodernidad) explicaría la resistencia, y los conflictos que todas las poblaciones occidentales demuestran hacia la policía y el Estado. En este punto, el trabajo de Robin se hace fuerte pues asume (in facto esse) que el adoctrinamiento interno opera en manos de las fuerzas policiales de la misma manera que en los estamentos militares (orientados a la seguridad soberana contra un enemigo externo), por manipulación del miedo. La resistencia contra ese poder no sería otra cosa que la evidencia sustancial de un movimiento democrático auténtico.

Análogamente, R. Bernstein explora la conexión entre religión y patriotismo para definir al miedo político. La tesis central de Bernstein radica en que la corrupción de las instituciones se da cuando las metas sobrepasan las capacidades éticas de la sociedad, cuando el objetivo se hace más importante que los pasos a seguir, eso debilita la capacidad de la sociedad para hacer frente a los totalitarismos. Desde dicha perspectiva, Bernstein toma las contribuciones de A. Arendt con respecto a la construcción del mal y su relación con el holocausto sucedido en Auschwitz. Definiendo previamente al mal como toda intención de trivializar la esencia humana, Bernstein asegura que una de las estrategias de los regimenes totalitarios consiste en monopolizar y manipular todo lo que en esta vida es espontáneo. Siguiendo este argumento, los grupos en el poder intentan imponer una lógica bipolar que construye dos realidades, rompiendo las posibilidades de toda negociación. El juicio de Eichmann no sólo nos recuerda hasta que punto gente ordinaria como nosotros puede cometer crímenes horribles, sino además enfatiza en la importancia de la responsabilidad en el seguimiento de las instrucciones. Bernstein discute la manera en que la corrupción aún dentro de los sistemas democráticos puede ser manipulada y transformada en una construcción de expansión ideológica. El voto universal, no es prerrequisito suficiente para afirmar que un país es democrático o no sino por el contrario lo que determina el grado de democracia es la capacidad de dialogar e intercambiar posiciones (Bernstein, 2006).

Lo que para Robin es cuestión de hegemonía para Bernstein sugiere cierto dogmatismo en el discurso que nada tiene que ver con la religión. El 
absolutismo de pensamiento no surge de la religión ni de la política, pero las utiliza, las corrompe y las presenta como instrumentos que "dignifican" sus intereses. En lo personal, el trabajo de Bernstein explora como la tergiversación y la petrificación de ciertos valores religiosos son funcionales para generar mayor legitimidad en un momento de la historia humana caracterizada por la incertidumbre y el temor. En efecto, los hombres son más proclives a la sumisión voluntaria cuando experimentan procesos de miedo, ansiedad e indecisión. Dentro de tal contexto, existe una tendencia inevitable dentro de las democracias occidentales al autoritarismo en cuyo caso la ciudadanía debería mantenerse expectante y en alerta (Bernstein, 2006). Tanto para Robin, Arendt, como para Foucault y Bernstein el miedo es tanto que político una herramienta (no el fin en sí mismo) para lograr el adoctrinamiento interno. Este miedo puede actuar por medio de un enemigo externo como interno.

Hanna Arendt, en Eichmann en Jerusalén, narra algo más que su propia experiencia como testigo del juicio al Coronel de las SS capturado en Argentina. Centrada en la tesis del show mediático conducido por el fiscal, Arendt asume que potencialmente Eichmann no era un asesino psicópata con ansias de tortura, sino un simple hombre cuyos apetitos políticos de progreso y bienestar lo llevaron a ser eficiente en su tarea. Lo que Arendt cuestiona, y por lo que ha sido tan fuertemente criticada, es la relación que existe entre lo moral y lo instrumental. En otras palabras, como la lógica instrumentaliza no reconoce razones morales. Lejos importa si Eichmann era bueno o malo, la cuestión es que todos somos potenciales Eichmann cuando nos movemos en el mundo sin espíritu crítico. Eichmann no solo no reconocía patologías psicológicas sino que tampoco era antisemita, admite Arendt, sino una banalidad que lo lleva a deslindarse de su responsabilidad y el respeto de la ley. Eichmann buscaba la aprobación del superior y no el mal del prójimo (Arendt, 2006). Esa es precisamente la diferencia entre un intelectual (cuyo interés es científicotécnico) movido por las fuentes financieras que el Estado pueda darle (y en tanto que empleado del mismo ya sea en el CONICET u otro organismo estatal) y el humanista cuya visión hólista del ser humano lo lleva a repreguntarse por las cuestiones esenciales (lo eterno, absoluto y trascendente valores claros de la ilustración). Todo filósofo, en este punto, debe convertirse en humanista más que en científico. De otro modo, corre el riesgo de caer en la monotonía y la profesionalización del saber académico; más interesado por expander su propio nombre y ego personal que por comprender.

\section{La Cultura Narcisista}

Es por demás interesante, dilucidar el papel que tiene el profesionalismo en nuestra vida diaria, pero también sus más nefastas consecuencias. Quien, movido por su curiosidad, lea una columna especial en un periódico, o vea un programa de televisión en donde se tome al temor como el principal objeto de debate, se dará cuenta que existe un fuerte apego entre este sentimiento indomable y los médicos, y psiquiatras. En la actualidad, el miedo se ha convertido en un fenómeno que ocupa la atención de la psiquiatría y la psicología como un indicador patológico de malestar el cual impide el buen funcionamiento del "hombre-maquina". Dentro de este contexto, el tratamiento 
del profesor Christopher Lasch sobre el tema se presenta como ilustrador. Precisamente, donde la mayoría considera que el aumento del miedo es producto de la conceptualización del futuro y la imposibilidad del Estado-Nación (ver influencia del existencialismo alemán), Lasch observa otra cosa.

En comparación a otros autores, la posición de éste autor puede catalogarse como pesimista. Existiría una tendencia, casi irreversible, a concebir el mundo externo como peligroso, catastrófico y caótico. Dicha tendencia es producto de un cambio de valores y cosmovisiones que aparecieron por vez primera con la modernidad. Ya nadie busca una solución a los problemas que pueden llevar a la catástrofe, sino que enfatizan en la supervivencia individual. A la cultura narcisista, que caracteriza la vida en nuestra sociedad, le cuesta comprender el futuro en parte a su desinterés por el pasado pero por sobre todo por la falta de tradición. El pasado sólo representa para la cultura narcisista una trivial forma de comercialización e intercambio (ver patrimonialización cultural). Los personajes de "la cultura" tienen un gran impacto en la opinión pública y las cuestiones de Estado.

Por otro lado, en tanto que el miedo se ha convertido en un valuarte de los "terapeutas" (como si fueran los únicos autorizados a examinar el fenómeno), el sujeto moderno ha subordinado todas sus habilidades a la "empresa" siendo incapaz de satisfacer sus propias necesidades. A diferencia de otros autores que hablan del declive del Estado, Lasch prefiere afirmar que el sujeto se ha convertido en dependiente del Estado y de las grandes corporaciones. El narcisismo, como patología social, refleja esa dependencia ya que obliga al ciudadano a no poder vivir sin la aceptación de otros (imagen grandiosa del self). La liberación del apego a la familia y a los lazos sociales contribuye a que el narcisista alimente su imagen desmesurada, pero a un alto costo, el aumento sistemático de la inseguridad (p. 28).

Asimismo, Lasch sugiere que el narcisismo opera redirigiendo el amor rechazado hacia el yo en forma de odio. Las necesidades no cubiertas por la madre pueden ser transformadas en fantasías de una "madre" imaginada. Por tal motivo, los pacientes narcisistas "suelen experimentar intensos sentimientos de vacío e in autenticidad. Aunque el narcisista puede funcionar en el mundo y a menudo encantar a otras personas (en no poca medida con el pseudoesclarecimiento de su propia personalidad), su devaluación de los demás, y su falta de curiosidad por ellos, empobrece su vida personal y refuerza la experiencia subjetiva del vacío. Carente de cualquier compromiso intelectual auténtico con el mundo - a pesar de su valoración frecuentemente inflada de sus propias habilidades intelectuales-, exhibe escasa capacidad para la sublimación. Por lo tanto depende de otros, de quienes requiere infusiones constantes de aprobación y admiración. Debe asociarse con alguien, vivir una existencia emocional, junto a su aproximación manipuladora, explotadora de las relaciones interpersonales, hace que esos vínculos resulten blandos, superficiales y profundamente insatisfactorios " (p. 62-63). Las imágenes malas del exterior lo tienen totalmente preocupado por la salud individual, casi hasta un punto hipocondríaco. El narcisista vive con un constante sentimiento de superioridad producto de su impotencia (como bien lo ha argumentado Zizek). La necesidad de admiración y superioridad son contrarias al envejecimiento. 
Quienes dependen de la autoafirmación por medio de la belleza, la juventud, fama o encanto de cualquier tipo se ven seriamente amenazados por el paso del tiempo. Cirugías estéticas, discursos pomposos, excelsos libros de historia vinculando a San Martín con los derechos humanos, deportistas exitosos y delirios de grandeza son algunas de las características que distinguen a los feligreses del culto $\mathrm{K}$.

Siguiendo el mismo argumento, Lasch llama la atención sobre la influencia de la historia y las fuerzas sociales en las neurosis individuales. Si los tiempos de Freud avistaban casos de histeria y fobia, hoy podemos observar problemas de trastorno narcisista y esquizoide. El hombre moderno no busca poder y gloria sino por medio de la aceptación de otro quien como él depende de la valoración de un tercero. La competencia y los altos grados de movilidad son funcionales a la sociedad del "espectáculo" cuya burocracia se encuentra abocada a la organización de una personalidad específica. La vida es una proyección de imágenes e impresiones grabadas reproducidas mecánicamente en forma de películas y fotografías. Para C. Lasch (1999), la medicina y sobre todo la psiquiatría se han esmerado en los últimos años en reforzar por medio de la terapia, la norma vigente por la cual el patrón creado verifica con el objetivo de buscar signos de envejecimiento a ser combatidos.

Ello sugiere que las condiciones modernas alientan la supervivencia del más apto o fuerte la cual queda plasmada en esa fascinación que todos tenemos por el cine catástrofe. La gente ordinaria ya no sueña con atravesar caminos plagados de obstáculos sino simplemente con sobrevivir a esas amenazas y en su ficcionalización se encuentra el grado de admiración que el ego narcisista necesita. La corrosión económica y la inestabilidad laboral han provocado que el sujeto de rienda suelta a sus deseos hedonistas en un presente mediato. Los hombres son cada vez más vulnerables al temor político. El día se vive como consecuencia de una falta constante de normas y reglas fijas (es decir, de ley). La ética protestante que vinculara al trabajo con la frugalidad, la creatividad, el auto-control y el progreso han dado paso a una nueva ética de la autoconservación propia del capitalismo. La primera noción de socialiabilidad que impregnaba la moral puritana, dio lugar finalmente al avance del privatismo a la vez que el progreso comenzó a depender de la "voluntad de poder" y la confianza en uno mismo. Lo político ha cedido al "show" de la política, admite Lasch, en donde el mensaje tiende a captar al electorado pero la práctica política va en un carril opuesto.

\section{El Arquetipo K}

Luego de su salida de Egipto Moisés condujo al pueblo de Israel durante cuarenta años luego de una gran opresión; lo mismo puede decirse ocurre con el profeta Mahoma cuando debe abandonar las Meca o incluso el pueblo de Israel tras la diáspora a Europa. El sufrimiento parece ser una variable importante en el génesis de todas, o la mayoría de, las religiones y sus héroes arquetípicos (Weber, 1987) pero no el único. El profesor F. Bauzá explica los héroes míticos cumplen un papel mediador el cual vincula a los hombres con sus dioses; lejos de ser personajes felices o perfectos, los héroes deben 
atravesar un camino plagado de peligros y sufrimiento por causa de un pecado (o falta) cometida. La mayoría de los héroes son personajes poco comunes (excepcionales), venidos de un linaje "sagrado" que han sufrido persecuciones políticas de reyes y príncipes. Con la redención del héroe (muerte) comienza un proceso de apoteosis en donde los dioses reciben al nuevo integrante del centro ejemplar cuya función radicará en interceder por los hombres cuando sea necesario (Bauzá, 1998), he aquí el segundo y tercer elementos del hecho religioso, la persecución política y la muerte.

El Héroe da su vida por sus semejantes en forma desinteresada para enfrentar a poderes hegemónicos que intentan controlar al pueblo elegido por Dios. Se comienza a perfilar en todos los ordenes de la sociedad, un nuevo discurso ligado "al triunfo del más débil" dando lugar al cuarto elemento. Quinto, existen compensadores directos e indirectos (el término ha sido extraído del profesor A. Frigerio) los cuales nivelan las frustraciones diarias de los ciudadanos o feligreses (Frigerio, 1999). La tesis de Frigerio es que las religiones o cultos populares ofrecen diferentes compensadores a las personas para satisfacer sus necesidades y frustraciones. En analogía al mercado, la religión vincula al hombre con su comunidad. Según este desarrollo, existen dos tipos de compensadores, los específicos y generales. Los cultos populares se caracterizan por tener una fuerte presencia de actores que piden por temas específicos trabajo, amor y salud (compensadores específicos) cuya retribución se agradece a corto-plazo. Las religiones (a diferencia de los cultos) cumplirían con una compensación más general satisfaciendo necesidades de pertenencia y trascendencia. Ambas tendencias coexisten en los feligreses lo cual explica el aumento de la religiosidad popular en América Latina (Frigerio, 1999). Misma observación puede configurarse al escenario político donde la persona "afligida" es compensada por medio de diferentes mecanismos. Sexto y último elemento, el pensamiento mágico por el cual las mentes de los feligreses se impermeabilizan frente al principio de realidad. Cabe aclarar el pensamiento mágico (a diferencia del racional) se basa en la fe, la imaginación y los deseos no distinguiendo la correlación causal de los hechos sino adaptando los efectos a las creencias previas. Cualquier evidencia objetiva no destruye el pensamiento mágico sino que lo afianza. El pensamiento mágica se resiste a ser contrastado con el principio de realidad; es como un gato siempre cae bien parado.

Todos estos elementos combinados confluyen en la creación de un arquetipo mítico (un modelo mágico y ejemplar) iluminador sobre el cual se emprende la batalla. Es cierto, nadie entra en una guerra sin un rey a quien defender, y no menos cierto es que muchos necesitan de uno para poder pensar, pero la realidad parece algo más compleja. Los sacerdotes del culto (K) necesitan no solo un texto sagrado y sus exégetas (muchos ven a Jauretche como su gran inspiración como así también a ciertos pseudo-intelectuales cuyas interpretaciones se nos quiere imponer como José Pablo Feinmann, Eduardo Gruner, Horacio González, Juan Pablo Mansilla, Ricardo Forster, cuyo nombre real no es ese precisamente sino Ricardo Nepomniaschy Forster etc) sino la posibilidad de participar en algo que los saque de su monotonía diaria. El ciudadano común ya no quiere ser oficinista, portero, carpintero o cartero sino "guardián del orden sagrado". Sin embargo, es algo engorroso involucrarse en 
la política, y el ciudadano se remite solamente a opinar en las charlas de café con familiares, compañeros de trabajo o amigos (despersonalización de la política). Uno de los éxitos incuestionables del culto $\mathrm{K}$ no ha sido otro que darles a personas corrientes la importancia de sentirse protagonistas de una era, de un sentir y de un rumbo hacia la felicidad "total". Este sentimiento desmedido y fantástico cumple una función catártica (como el arte o del deporte) ya que saca el sujeto moderno de su completo anonimato, sana sus heridas y lo recoloca transformado en un ente "narcisista" necesitado de reconocimiento y delirio. La música, elemento propio, de quienes se preparan para la batalla (los guerreros) se encuentra presente en todo culto, como una necesidad de vincularse a la pregunta ¿moriré en el campo de batalla?. Esa parece ser razón suficiente para observar porque tantos artistas musicales y actores se han plegado (a-críticamente) al culto K. Lo estético, por su parte, se desborda en los escenarios patrios y las fiestas populares como rituales orgiásticos de grandeza. Existe una fuerte teatralización de la realidad política que el Culto $\mathrm{K}$ controla por medio de la palabra. Ella es importante en toda religión, o acaso los católicos no repiten "esta es la palabra de Dios", los árabes "es la enseñanza del profeta", ¿la sagrada inquisición torturaba por lo que se decía y no por lo que se hacía?. La palabra (oral y escrita) y no la práctica política se transforman en cuestiones de base para la construcción de la hegemonía K. Empero, con excepción del budismo (que es una filosofía y no una religión) ningún culto puede auto-realizarse sin la presencia del mal.

El mal, en este escenario, es encarnado en última instancia por el mercado, los medios hegemónicos, la derecha, los militares y los civiles golpistas (que tanto preocupaban al señor Jauretche) el Fondo Monetario Internacional, Estados Unidos e Inglaterra y la experiencia privatizadora de los años 90 como así también todas las fuerzas políticas opositoras al "frente para la Victoria" pero por sobre todo el partido que creara el empresario argentino Mauricio Macri, el PRO. En algún punto, el arquetipo mítico cumple un doble juego, por un lado da protección al mal "denominado pueblo" por medio de la imposición de un deber sagrado, pero en una segunda instancia, ese "pueblo" comienza a hacerse cada vez más reducido hasta que los sacerdotes (políticos) terminan por gobernar a espaldas del pueblo que dicen "defender". Este es el origen de toda persecución política sea el régimen e ideología que sea.

Dado el modelo teórico para comprender el fenómeno K, procedemos a unir las piezas que legitiman su arquetipo mítico. La década de los 90 representó para el imaginario argentino un gran trauma psico-social. Durante la presidencia de Carlos Saul Menem, se instauró un régimen de paridad cambiaria para frenar la híper-inflación del gobierno precedente (R. Alfonsín) pero paradójicamente se cayó en un proceso de deflación en donde las industrias dejaron de producir generando un gran índice de pobreza, desocupación y pauperización en la sociedad argentina. Este hecho se constituye como el "gran sufrimiento" que ha dado lugar al nacimiento del Culto $\mathrm{K}$ y a su teoría "conspirativa". Los poderes internacionales, con Estados Unidos a la cabeza, junto a los organismos financieros con una complicidad de la elite empresaria local hundieron a la Argentina en la más honda pobreza. Como modelo neoliberal de los 70 y la desaparición de miles de disidentes políticos, los "derechos humanos" se transformaron en una razón política de Estado para la concreción de metas 
específicas y correctivas, ora "reestablecer la grandeza de la nación Argentina y fomentar un modelo de inclusión social de todas las clases relegadas hasta el momento". Pronto el matrimonio K tanto Cristina como Néstor, desde 2003 a hoy se han transformado en los héroes míticos quienes podrían sacar el pueblo argentino del letargo en donde se encontraban. Este proceso de apoteosis culminó, sin lugar a dudas, con la muerte accidental del ex presidente Néstor Kirchner (quien según el Culto dio su vida para salvaguardar dicho sentimiento de grandeza). Luego de su muerte, la calle se vio empapelada de carteles que decían "Néstor con Perón y Cristina con el pueblo".

La redistribución de la riqueza, aquí cabe definir si riqueza se iguala a masa salarial o capacidad de ahorro, conformó la base para imponer el discurso que pregona sobre protección del más débil, el pobre y/o trabajador pero cínicamente lo deja a la deriva. El nuevo culto $\mathrm{K}$ rompió relaciones (como en todas las religiones) con su antiguo padre "el peronismo clásico" haciéndose de una nueva identidad, un nuevo discurso, una nueva cosmovisión y razón de existir. El triunfo, elemento importante de todas las religiones, dio nombre al partido, "frente para la victoria" y los diferentes actores políticos activaron los resortes para satisfacer ciertas necesidades de ciertos grupos a la vez que dejaron a un lado otras de otros. Los disidentes, grupos monopólicos informativos, grupos de presión fueron simbólicamente "escarchados" y perseguidos bajo una lógica bipolar excluyente: ustedes traidores a la patria deben ser aleccionados (inquisición). Los enemigos del culto como Lucifer, Prometeo, Edipo y los rebeldes de Dios (Markale, 2006) son actores fundadores del mal. El aparato propagandístico del culto $\mathrm{K}$ utiliza la fuerza de la palabra como forma disuasiva erosionando y vaciando el contenido. Los diversos artistas e intelectuales que pasan por programas como 6/7/8 no han sido convocados para hablar de su campo de estudio sino de otra realidad. El prestigio del intelectual es usado, por estos grupos, para afianzar la legitimidad de los argumentos. Pongamos el siguiente ejemplo, el físico nuclear $X$ consagrado por ganar el novel gracias a su teoría de la partición de átomos no es citado para explicara claramente sus hallazgos sino para hablar de una realidad social que les es ajena como experto y desconoce. En este mismo sentido, la Feria internacional del Libro ha sido testigo de como miles de ejemplares (cuyos autores se presentan como filósofos o intelectuales) legitiman ideas que de ningún representan a la comunidad como tal ni mucho menos tienen el prestigio de un manuscrito arbitrado en una revista especializada. El debate no es funcional a la ideología, siquiera al culto, sino al bolsillo de los autores.

Cuando Fito Páez, escribe su "odiosa" carta criticando el voto porteño, la comunidad se pregunta ¿Qué le ha pasado?, faltó preguntar ¿que clase de culto o secta puede hacer algo así en la mente de un ciudadano libre?, tal vez sean cristianos diría Séneca o Cicerón... nooo son kirchneristas. Veremos que el discurso K no difiere mucho de un grupo fundamentalista musulmán.

El empresario M. Macri encarna el avance desmedido de la modernidad y la racionalización de la vida pública. El culto $\mathrm{K}$, no solo no negocia con esta fuerza maligna sino que ordena a sus exégetas una crítica insustentada. ¿Por qué los intelectuales dejan crecer sus cabellos y barbas como Cristo?, ¿Por 
qué Forster (2009) y Sarlo (2011) se empecinan con un intelectual como Benjamín que a comparación de otros ha dicho tan poco? (no por falta de capacidad sino por su abrupta y corta vida, recodemos Benjamín se suicida en al frontera hispano-francesa escapando del régimen nacionalsocialista). Benjamín es un pensador comprometido y preocupado con el avance de la modernidad, además de un mártir que inspira a otros mártires. Su tesis principal radica en comprender el principio de la réplica o copia artística (reproducción técnica). Acomodado burgués de tendencia marxista, Benjamín considera que el intelectual no debe militar en política porque pervierte su propia esencia y legitima la reproducción instrumental. Al igual que Arendt, Benjamin consideraba que el instrumentalismo moderno llevaba al hombre a ser un autómata. La obra de arte es concebida antes de ser copiada o reproducida como auténtica y su autenticidad radica en su singularidad mientras que la copia conlleva a la secularización y se acerca a las masas; un ejemplo de lo último es la exhibición de las mal llamadas obras de arte en donde el arte "pierde" su aura (Benjamín, 1982). En consecuencia, Benjamín fue adaptado (postmortem y vinculado a la E. de Frankfurt) a la hegemonía de los mass-media; es posible que el mismo autor en vida, haya asentido con esta tesis, empero lo que es importante destacar es que Benjamín sienta las bases para la instauración de un binomio simbólico (autenticidad vs. falsedad) que se corresponde perfectamente con las contribuciones jauretchianas y el Culto $\mathrm{K}$. Benjamin es ante todo un pensador de la cultura pero cabe mencionar la palabra cultura, tiene una raíz etimológica interesante, deriva tanto de cultivo lo cual denota trabajo como de culto lo cual se refiere al sacrificio. Ese sacrificio es llevado a cabo ante los dioses para proteger el cultivo de las fuerzas naturales, es un regalo a los dioses en búsqueda de protección y cuidado. Por lo tanto, el culto siempre evoca a un culpable quien carga sobre si las responsabilidades de todos los miembros del grupo (chivo expiatorio). Identifiquemos entonces ¿quienes son los culpables del orden-K? La corporalidad es una pieza clave para comprender la sacralización de los muertos. Como la falta de un cuerpo en el caso cristiano es suficiente para nombrarlo Dios, hoy los desaparecidos cumplen un rol sagrado similar.

\section{Análisis de la Carta publicada por Fito Páez en Página 12}

Las elecciones del 11 de Julio de 2011 dejaron un triste saldo para el bloque $\mathrm{K}$ en la ciudad de Buenos Aires que coronó a Mauricio Macri como ganador de la primera vuelta con poco más del $47 \%$ de los votos porteños. Al otro día, se publica en el periódico Página 12 una carta firmada por Fito Páez titulada: La Mitad. Si bien el contenido de dicha carta solo es la expresión del señor Páez, lo cierto parece ser que expresa, simplifica y esboza el discurso de una época, y de un sentir con respecto a "otros" que piensan diferente. La carta se encuentra marcada por una fuerte resistencia al avance del mercado y a lo que su autor llama "la mezquindad". Satisfechos por motivos puramente económicos, y de espaldas a la "revolución nacional", la mitad de los porteños (que votaron a Macri) estarían colonizados por su propia mezquindad y egoísmo. Este grupo, movido por los ejes del mal, se ha transformado en algo indescriptible, algo que abruma y repugna (falto decir afeminados, anormales, etc). La diversión como motivo fundante del mercado es no solo alienante sino 
amenazadora para la verdadera felicidad. En ese "ser-estúpido", el porteño se convierte en digno de repulsión. Los derechos humanos, o la complicidad de ciertos sectores con respecto a los desaparecidos durante la última dictadura (1976-1982) juegan un rol importante como reforzador simbólico de esa maldad indescriptible. La figura del ex presidente Carlos Saúl Menem aparece nuevamente en la pluma del texto de Páez como el principio mítico caótico que amenaza el orden o el bien de la República.

Nunca Buenos Aires estuvo menos misteriosa que hoy. Nunca estuvo más lejos de ser esa ciudad deseada por todos. Hoy hecha un estropajo, convertida en una feria de globos que vende libros igual que hamburguesas, la mitad de sus habitantes vuelve a celebrar su fiesta de pequeñas conveniencias. A la mitad de los porteños le gusta tener el bolsillo lleno, a costa de qué, no importa. A la mitad de los porteños le encanta aparentar más que ser. No porque no puedan. Es que no quieren ser. Y lo que esa mitad está siendo o en lo que se está transformando, cada vez con más vehemencia desde hace unas décadas, repugna. Hablo por la aplastante mayoría macrista que se impuso con el límpido voto republicano, que hoy probablemente se esconda bajo algún disfraz progresista, como lo hicieron los que "no votaron a Menem la segunda vez", por la vergüenza que implica saberse mezquinos".

Es interesante notar que para el autor de la carta, Buenos Aires tiene género femenino, es una mujer misteriosa. En tanto que ciudad (la), Buenos Aires es la prostituta de la corrupción moderna. El orden $\mathrm{K}$ aborrece al menemismo y al neo-liberalismo de una manera poco-convincente, pero ese no es el punto. La inacción y la falta de iniciativa en la actividad pública "militante" es para el converso K Fito Páez una cuestión clave de la derecha liberal. Y Nuevamente arremete:

"Nunca Buenos Aires estuvo menos misteriosa que hoy. Nunca estuvo más lejos de ser esa ciudad deseada por todos. Hoy hecha un estropajo, convertida en una feria de globos que vende libros igual que hamburguesas, la mitad de sus habitantes vuelve a celebrar su fiesta de pequeñas conveniencias. A la mitad de los porteños le gusta tener el bolsillo lleno, a costa de qué, no importa. A la mitad de los porteños le encanta aparentar más que ser. No porque no puedan. Es que no quieren ser. Y lo que esa mitad está siendo o en lo que se está transformando, cada vez con más vehemencia desde hace unas décadas, repugna. Hablo por la aplastante mayoría macrista que se impuso con el límpido voto republicano, que hoy probablemente se esconda bajo algún disfraz progresista, como lo hicieron los que "no votaron a Menem la segunda vez", por la vergüenza que implica saberse mezquinos".

La búsqueda de un pasado mítico siempre ejemplar de harmonía y ejemplaridad es el otro de los elementos comunes en los cultos. La necesidad de retornar a los fundamentos del pasado (base propia del fundamentalismo religioso) justifica la lucha de los liberadores del presente (el militante).

Da asco la mitad de Buenos Aires. Hace tiempo que lo vengo sintiendo. Es difícil de diagnosticarse algo tan pesado. Pero por el momento no cabe otra. Dícese así: "Repulsión por la mitad de una ciudad que supo ser maravillosa con 
gente maravillosa", "efecto de decepción profunda ante la necedad general de una ciudad que supo ser modelo de casa y vanguardia en el mundo entero", "acceso de risa histérica que aniquila el humor y conduce a la sicosis", "efecto manicomio". Siento que el cuerpo celeste de la ciudad se retuerce en arcadas al ver a toda esta jauría de ineptos e incapaces llevar por sus calles una corona de oro, que hoy les corresponde por el voto popular pero que no está hecha a su medida. No quiero eufemismos. Buenos Aires quiere un gobierno de derechas. Pero de derechas con paperas. Simplones escondiéndose detrás de la máscara siniestra de las fuerzas ocultas inmanentes de la Argentina, que no van a entregar tan fácilmente lo que siempre tuvieron: las riendas del dolor, la ignorancia y la hipocresía de este país. Gente con ideas para pocos. Gente egoísta. Gente sin swing. Eso es lo que la mitad de la Ciudad Autónoma de Buenos Aires quiere para sí misma.

La "lógica paranoica" se encuentra presente el párrafo precedente por medio de las "fuerzas escondidas en la oscuridad" que han conspirado y siguen haciéndolo en el presente contra las fuerzas del bien y orden-K. Esa mitad oscura, corrompida y porque no "podrida!" se contrapone, implícitamente a otra mitad "pura" y "prístina", una mitad de "bien". La emulación del orden mítico que diera (por vía de un golpe de estado) fin al gobierno del General Juan D. Perón en 1955, culminará con la tragedia del orden K. La puesta en escena internalizada por la mayoría de los feligreses del culto $\mathrm{K}$ exige un final trágico porque su propio arquetipo mítico ha sido trágico. Como bien dice Kierkegaard, a diferencia del padre de la fe, el héroe trágico adquiere su fuerza por medio del sacrificio egoísta en pos de sus propios intereses. Así como no nos arrepentimos para dejar de pecar, sino para seguir haciéndolo, los arquetipos, sus héroes y prácticas no solo se encuentran condicionados por su propia elaboración mito-poética sino también por las fallas que sus propios ancestros cometieron (profecía autocumplida). El goce de los jerarcas del orden $\mathrm{K}$ no está en el éxito de su gestión, sino en la crispación que dieron origen a la forma de hacer política en los 70, y a la posterior destitución del orden democrático. Los tonos de Eva Perón imitados por CFK como así también las frases (pocos célebres) de sus subordinados emulan el orden mítico de una época que ya no es pero que pervive en un discurso específico: ¿hay algún peligro en imitar a nuestros héroes fundadores?, después de todo, todos nosotros somos víctimas de nuestras propias profecías auto-cumplidas. ¿Porque un desaparecido vale más que un sobreviviente?. Para responder dicha pregunta, es necesario adentrarse en los cuestionamientos que la filósofa méxicana María Pía Lara hace a la narración del Mal.

\section{Construyendo el Mal}

Sin lugar a dudas, las palabras genocidio y desastre moral han sido acuñadas en el devenir del siglo XX luego de los crímenes perpetrados por el nacionalsocialismo alemán en la Segunda Gran Guerra. El impacto moral de lo ocurrido no solo sacudió la consciencia de Occidente sino despertó el silencio de muchas instituciones que con su silencio permitieron el "Holocausto". Es por ese motivo que uno puede suponer que el mal puede ser narrado por medio de 
los testimonios de aquellos que han sobrevivido y lo han padecido, pero esa no es la única forma de comprender la presencia del mal.

Los imaginarios sociales tejen diferentes discursos alrededor de lo que podemos llamar "el mal", todos ellos sujetos no sólo a la propia interpretación sino también a los juicios políticos que se hacen de catástrofes como Auschwitz o incluso las sangrientas dictaduras militares en América Latina. En este contexto, el libro de María Pia-Lara titulado Narrar el mal se constituye como un valiente intento de retornar al juicio ético que los intelectuales deben hacer cuando se está en presencia de regimenes totalitarios. Basada en las contribuciones de filósofos de primera línea como Arendt, Habermas, Adorno o Levi, Pia-Lara afirma que el mal es descrito como la convergencia entre la necesidad de justicia, la reparación y la postura moral de los involucrados. Ciertamente, la actual interpretación del impacto que implican los genocidios es posible gracias a la articulación de filtros morales que buscan en el lenguaje una nueva palabra para aquello que por su crueldad no puede ser narrado. Es exactamente el caso de términos como genocidio (Lemkin) o totalitarismo (Arendt), en los que se busca la significación semántica tanto de aquellos que han sufrido los crímenes de lesa humanidad perpetrados en Latinoamérica como también aquellos que en su silencio no pueden hablar. Los seres humanos tendemos a intelectualizar la contingencia de manera tal que proyectamos nuestras propias características. El proceso de antropormofización tiene como objetivo hacer creer a uno que tiene la posibilidad de evitar aquello encriptado en el destino, sobre todo la crueldad de otros.

Pia-Lara reconoce que la crueldad es un elemento importante de la identidad y la naturaleza humana, del cual nadie puede deslindarse. No obstante, los intelectuales tienen el deber de ejercer un juicio moral que no sólo describa los eventos sino que permita a la sociedad un aprendizaje moral de las catástrofes. Para ello, nuestra autora habla de "juicio reflexionante" como aquella capacidad humana por comprender el espectro del mal según la posición moral. Cada juicio reflexionante debe ajustarse a los hechos particulares y no a leyes universales. Si partimos de la base que los filósofos han estudiado históricamente al mal desde una posición universalista (juicio determinante), como Arendt ha demostrado, es necesario zambullirse en el complejo mundo de las significaciones y las narrativas para llegar a un juicio particular. Ello ha sido precisamente lo que llevo a intelectuales de gran renombre como $\mathrm{C}$. Schmitt o M. Heidegger a afiliarse a regimenes totalitarios. La amoralidad o carencia de juicio moral que caracterizó a la generación alemana de 1930-45 posibilitó el advenimiento de Hitler al poder. Es por ese motivo, admite PíaLara, que ningún intelectual que se precie de tal debe mantenerse indiferente al juicio moral de los eventos políticos.

Desde esta novedosa perspectiva, Pía-Lara llama a la reconstrucción del imaginario colectivo, enraizado en la historia, como una forma de recordar nuestra propia propensión al mal. Después de todo, la "banalidad del mal" (Arendt) se refiere a la posibilidad que cualquiera en cualquier momento pueda ser un arquetipo superficial del mal. Dadas estas condiciones, los intelectuales latinoamericanos están siendo llamados a construir la historia como algo más 
que historiadores, simplemente como observadores morales de la historia. Tal vez una de las cuestiones que hace más terrorífica la violación de derechos humanos es la complicidad de aquellos que han silenciado el sufrimiento de "los otros".

A lo largo de su trabajo, Pia-Lara examina como los regímenes totalitarios se hacen eco del sufrimiento humano para construir un enemigo externo o interno en el cual lavar y expiar sus propias culpas. La figura del enemigo es construida por medio de un proceso de "semantización" por el cual se le atribuyen estereotipos negativos que van desde una seria amenaza para el estilo de vida o el Estado hasta su sub-humanización. Desprovisto el grupo minoritario de las categorías que le dan su humanidad, su exterminación puede sólo ser una cuestión de tiempo y de mera formalidad. La exterminación existencial deviene luego de la anulación de la personería jurídica de la víctima. Nacen de esta manera las "limpiezas étnicas". La tergiversación del discurso ético y de la moral es posible gracias al ejercicio de un poder-total que transforma prácticas no éticas en éticas simplemente en aras de legitimar su ideología.

No obstante, en cierto sentido la moral colectiva puede ser manipulada por cierto grupo de políticos inescrupulosos. El discurso de lo moral evoca no solo el sufrimiento de aquellos que no han sobrevivido por el cual tampoco pueden "hablar" sino la posibilidad de ser reelaborado y manipulado políticamente según los intereses contextuales de quienes ejercen el poder. Para ello se nutren de términos que se encuentran en el bagaje cultural y en el lenguaje y los re-elaboran según sus propias conveniencias. En contraste con Slavoj Zizek, quien llama a la intelectualidad a no plegarse moralmente a las acciones políticas (simplemente porque los políticos no buscan fines morales), Pia-Lara argumenta que es estrictamente necesario aprender de las catástrofes pasadas para que éstas no vuelvan a repetirse. La evolución moral es una de las piezas claves para la evolución de una civilización como tal. Sin embargo, la autora reconoce que en ciertos momentos los políticos y las estructuras partidarias manipulan a su favor hechos trágicos que han sucedido (objetivamente) de tal manera que al hacerlo crean su propio discurso unívoco de la tragedia (Zizek, 2009). Nutridos de una sola visión, la oficial, estos personajes socavan las posibilidades de llegar a un entendimiento concreto y cimientan las bases para el advenimiento de las más siniestras dictaduras: la dictadura de los Derechos Humanos

El libro Narrar el mal se corresponde con un interesante intento de analizar la convergencia entre ética y política, así como también de explorar las profundas reminiscencias del trauma psicológico. Alternando trabajos de diferentes escuelas, Pia-Lara presenta un debate que a la luz de los hechos trágicos que han suscitado la desaparición forzosa de personas en Hispano-América se vislumbra como ilustrativo, y no por eso menos polémico. El dolor humano, el recuerdo, el no-recuerdo y la manipulación de aquello que se debe recordar es uno de los más interesantes dilemas de la evolución moral. Pia-Lara reconoce la postura contraria de Zizek con respecto a este tema hasta el punto en que ella misma admite que Zizek confunde, por medio del juego entre sueño y realidad, la conexión entre lo bueno y lo malo. 
A manera de introducción, recordamos al lector la tesis de Zizek donde se afirma que nuestra limitada capacidad de comprender los eventos del mundo circundante nos obliga a tomar una posición moral parcial, siempre ideológica. Una de las cuestiones importantes que el intelectual debe tener en mente es no tomar ninguna posición moral y entregarse a lo pasivo. La posición pesimista de Zizek se basa primeramente en una concepción nihilista del mundo moral en donde solo hay dominadores y dominados, ninguno de ellos con el monopolio moral. En uno de sus trabajos más polémicos, Sobre la violencia, Zizek considera que la imposición simbólica de nuestras preferencias se constituye como la principal causa de violencia. ¿Por qué la muerte de un niño estadounidense vale más que mil congoleses? $O$ ¿Por qué ciertos derechos son más humanos que otros?, es la pregunta que dispara Zizek a lo largo de su libro, una curiosa, fogosa y controvertida discusión acerca de cómo se estructura la violencia en las sociedades.

Dos tipos de violencia coexisten en nuestra vida cotidiana, la violencia simbólica ejercida por la exclusión que denota el lenguaje y la sistémica cuya dinámica se encuentra enraizada en el funcionamiento de la economía y la política. La simpatía por las víctimas de la violencia, la caridad y otros artefactos similares ponen en evidencia que nuestra visión moderna de lo que es o no es violento se encuentra muy sesgada. Zizek llama a no implicarse en la "falsa urgencia"; una tragedia como puede ser el último terremoto de Haití o incluso el del vecino país de Chile conlleva a implicarse con ayuda "humanitaria", "donaciones" y apoyo financiero a los afectados, pero paradójicamente lejos de lograr un verdadero desarrollo, el sistema consigue replicar ciertos desajustes materiales que llevaron al desastre. De igual forma, Zizek considera que los empresarios capitalistas encerrados en la virtualidad de su lujo apelan constantemente a las infamias de este mundo como son la pobreza, la calamidad, el hambre etc. La constante necesidad de proteger al más débil no ayuda a la situación sino la empeora porque los políticos necesitan de la debilidad para aumentar su legitimidad política. Misma lógica puede aplicarse al asistencialismo $\mathrm{K}$, las causas reales del proceso inflacionario de alimentos en todo el mundo (financiero por agotamiento de la onza-oro en la reserva federal), la progresiva desindustrialización, altas tasa de interés producto de la falta de liquidez bancaria, la precariedad del trabajo (que no son fenómenos argentinos sino capitalistas) no son discutidas de lleno y en profundidad. Pues siguiendo este razonamiento, si el capital es el mal de todos los males como asumen los primeros marxistas ortodoxos (véase concepto de la plusvalía), ¿porque un Estado se esmera por poner una mayor cantidad de masa salarial en mano de los trabajadores?, ¿no significa ello mayor alienación y dependencia?, ¿dando más dinero al pueblo no legitimamos implícitamente el aumento de la pobreza?. Esta contradicción intelectual, lamentablemente, no ha sido respondida -o no puede ser respondida- por ningún exegeta del culto $\mathrm{K}$.

Retornemos por un instante a Zizek. Según el filósofo esloveno, luego de la masacre del nacionalsocialismo, siempre condenable, los estados europeos que en principio miraron para otro lado, se vieron en un estado de culpa tal que promovieron la creación de un Estado Judío. Pero lejos de ofrecer sus propias 
tierras en señal de verdadero arrepentimiento, emplazaron a Israel en medio de los estados musulmanes. Este acto primero de violencia cínica inició una escalada que hasta nuestros días es difícil de detener. La víctima, en este caso, llegó a ser victimario por medio de la manipulación del discurso que representa el "holocausto" como construcción simbólica. Sabemos que ha ocurrido pero su misma manipulación lo hace justificable, en consecuencia el discurso "antisemita" continúa vivo por regla inversa.

El mismo ejemplo puede observarse en la Argentina contemporánea con la manipulación que ciertos políticos hacen sobre la violación de los derechos humanos. Sabemos que son deplorables desde cualquier perspectiva, sabemos que han existido y tenido lugar, pero también sabemos que la tergiversación ideológica que lleva a los actuales gobernantes argentinos a fagocitar sus causas presentes por medio de la expiación de los llamados "desaparecidos" termina implícitamente legitimando el orden represor que imperó en los setenta. De la misma forma en que la víctima se transforma en victimario, el Estado que hoy apela "al terrorismo de estado de los setenta" legitima el terror por medio de la percusión ideológico-político, el "apriete a la prensa" y el "escrache popular" y otras formas. Formas sutiles y soslayadas de represión que llevan a un mandatario de primer nivel a expresar "si fuera una genia haría desaparecer a algunos" en un discurso llevado a cabo el 19 de Enero de 2010 en el Auditorio de la Biblioteca Nacional; o al periodista Eduardo Aliverti a exclamar (cuando recibe su premio Martín Fierro : "Ya que aquí se ha pedido mucha escupidera a Cristina, a Néstor y al Gobierno, respecto del miedo, y perdón si soy repetitivo: acá se chupó demasiada gente, se picaneó, se violó, se tiraron cadáveres al mar, como para que venga alguno acá a decir que tiene miedo ... tengan más respeto por las palabras, algunos que dicen que tienen miedo". Nuevamente véase, como el culto hegemoniza la interpretación de la palabra. Esta falta de respeto por el miedo ajeno, es explicable por medio de un arquetipo bipolar, es como si yo dijera, ¿debido a la matanza de miles de indígenas inocentes, se prohíbe la representación sindical?

Tal vez éste sea uno de los puntos que Pía Lara no expone con total claridad en su interesante trabajo, un punto que aún sigue presente en "la memoria construida" de quienes llamamos víctimas puede ser plausible de manipulación política. Los derechos humanos pueden ser una formidable arma política de miedo y adoctrinamiento interno por medio del temor. Zizek no se equivoca cuando sugiere que una de las cuestiones más paradójicas de la historia es ver como las víctimas evocan y replican el discurso legitimante de sus victimarios. Puede compararse realmente al Culto K con la década de los 70 ?.

Esto no significa de ninguna forma que las prácticas de los gobernantes actuales sean comparables a aquellas que tiñeron de sangre la década del setenta como así tampoco se puede afirmar que las políticas actuales del Estado de Israel sean estrictamente equiparable a los crímenes sistemáticos de Auschwitz (tal vez esta es una de las exageraciones en las que incurre Zizek); no obstante, la relación dialéctica amo/esclavo explica como se acuña la fina frontera moral entre perdonar o hacer aquello que nos hacen con el riesgo de repetir la tragedia; un punto en donde la teoría de Zizek es débil (Zizek, 2009b). 
Desde una perspectiva nietzscheana, Zizek asume (en varios de sus trabajos) que una de las cuestiones más siniestras del cristianismo han sido la expiación sin pena de los pecados. Nuestro autor sugiere que la moral judeocristiana que "todo lo perdona" tiende a expandir la ofensa pues quien siempre es perdonado tiene licencia para seguir pecando. De esta forma, el crimen se ha convertido en uno de los valores culturales de Occidente (Zizek, 1989) (Zizek, 2003) (Zizek, 2009b). Partiendo de la base que toda ofensa viene acompañada por un sentimiento de culpa (el cual puede ser aceptado o rechazado) que permite no solo redimir la falta sino reforzar el lazo de solidaridad, Zizek olvida que el "verdadero" arrepentimiento no comienza con la purgación de la pena sino con la reconversión moral del arrepentido, quien en su proceso de culpabilización se compromete a no cometer la misma falta nuevamente a la vez que resarce a la víctima por voluntad propia. El caso Mandela en Sudáfrica explica la forma en que el perdón puede ser políticamente transformado de manera positiva.

El problema, precisamente, con las causas de crímenes de lesa humanidad perpetrados durante la dictadura 76/82 en Argentina es que no existe un sentimiento genuino de arrepentimiento. Como resultado, tanto víctimas como victimarios caen en un sentido negativo de la reciprocidad que traba la evolución moral de la cual nos habla Pía-Lara. Precisamente, en el "odio de todo lo que el enemigo representa" se termina reforzando su espíritu. Casi en forma idéntica a una posesión espiritual. En este punto, el exorcismo y la inquisición de quienes han vendido su alma al diablo se corresponden con dos tácticas violentas de todo culto. Pero el peligro radica en que el espíritu del victimario pasa de dominador a dominado con mucha facilidad, incluso bajo riesgo de poseer al mismo exorcista. Si bien cambian los actores, en el fondo, el problema parece ser el mismo. Cometemos un grave error al juzgar la historia con los ojos morales de nuestra propia vida y época; o acaso la conquista de América no fue llevada a cabo gracias a la complicidad de otros grupos aborígenes esclavizados antes de la llegada de los españoles?, o lo que es peor ¿no fue el poder civil quien salió a la calle para vitorear el golpe militar del 76 y luego ratificado con un campeonato mundial y una invasión fallida a las Malvinas?. La mejor forma de hacer filosofía es preguntarse, la duda es al buen filósofo un don que el religioso rechaza. La fe no tiene lugar para la duda o para las posiciones intermedias, exige todo de su huésped.

\section{Conclusión}

Somos hijos de nuestra época y resultado del propio devenir histórico; nuestros problemas para el diálogo y el consenso no se explican por sátiras o pseudotesis sobre la división internacional del trabajo sino por nuestra disposición cultural. A lo largo de este trabajo hemos intentado explicar y describir, como la mayor objetividad posible, la narrativa kirchnerista y como ésta se ha posicionado en una nueva forma de hacer y sentir lo político. Si el 20 de Diciembre de 2001 significó un quiebre en la forma de vivir el espacio público a la vez que una clase media descreída de la política se recluyó sobre las promesas del mercado, el matrimonio K no solo le dio a la Argentina una razón para volver a creer en ella, sino que sentó las bases para un culto (religioso) cuyos alcances quedan aún inconclusos. Bajo el lema conspirativo -casi 
paranoico- se instauró en la Argentina contemporánea un modelo político dictatorial que avasalla la libertad de las personas y la credibilidad de las instituciones so pesar de un bien mayor, la defensa de los pobres o una supuesta "democracia". Un discurso político que intenta dialogar con un pueblo fabricado que en ocasiones está incluso contra ellos mismos, pues ese pueblo es un rebaño al cual debo proteger.

A través de la lectura del presente ensayo uno puede deconstruir los diferentes cultos políticos del siglo XX desde el Stanislismo, el Mccartismo hasta el nazismo o la democracia corporativa de Estados Unidos hoy. Cada uno de ellos, con diferentes alcances y bajo diferentes métodos, ha creado un discurso legitimador el cual descansa en un bien superior (cuasi-mesiánico) cuyos héroes se suponían por fuera del sistema normativo en una sociedad que no respeta la ley sino que hace la norma a medida que la necesita. En ese contexto, el miedo político (al infierno o castigo) se transforma como un mecanismo aleccionador por el cual se permite un adoctrinamiento interno. A diferencia de los Estados Unidos donde el enemigo es externo (terrorismo islámico), en Argentina la lógica se dirime desde dentro, con un cómplice infiltrado que amenaza la "prosperidad nacional". Rechazar el culto K es, en primera medida, defender las doctrinas del libre-mercado que han pauperizado el orgullo nacional o mancillado a "nuestras mujeres" diezmado a una generación o incluso ha confabulado en la desaparición de miles de personas.

El proceso de victimización (narcisista), sufrimiento y posterior culpabilización (tan observables) del culto $\mathrm{K}$ actúan como mediadores simbólicos frente a una realidad muy compleja. Los medios masivos de comunicación, o mejor dicho los medios masivos de des-comunicación, dicotomizan en opuestos una realidad que se modifica así misma una y otra vez. Lo ejemplar del profeta no se da por su contenido sino por su rol de vocero divino frente a los hombres. El mensaje religioso es ajeno a las normas, como afirmaba S. Kierkegaard en Temor y Temblor. La salida del trauma, como hecho inicial, ha sentado las bases para la emergencia del culto $\mathrm{K}$, los poetas, artistas, y pseudointelectuales excitados por el fervor emocional y nacional han hecho el resto (casi involuntariamente). Ser pensante es una característica que estimula a los feligreses del culto $\mathrm{K}$ y aquellos que piensan diferente son deshumanizados como "alineados" por los medios masivos de comunicación o lo que es peor "cipayos y traidores".

Luego de todo el argumento expuesto, el legado de pensadores como Arendt, Foucault, Bernstein y Robin no solo es ilustrador sino que se transforma en un mensaje que nos alerta sobre la realidad social, razón suficiente para que los intelectuales se mantengan ajenos a la "voluntad de poder". El síndrome Séneca (consejero del Emperador Nerón que muere trágicamente) tan de moda en nuestros tiempos dentro de los círculos intelectuales transforman el pensamiento en dogma, y a los pensadores en escribas y/o feligreses, pues ¿Quién tiene la osadía de compararse a César, nuestro patriarca del orden sagrado?; uno infiere que tal vez haya que volver a ser como los primeros cristianos, críticos y esperanzados. 


\section{Referencias}

Agulla, J. C. (1986). Ideologías Políticas y Ciencias Sociales: La experiencia del Pensamiento Social Argentino (1955-1995). Buenos Aires, Instituto de Derecho Público, Ciencia Política y Sociología.

Arendt, H. (2006). Eichmann en Jerusalén. Barcelona, Editorial Debolsillo.

Aronoff, M. "Introduction". In Aronoff, Myron. (Editor), 1984. Religion and Politics. New Brunswick, Transaction Books.

Balandier, G. (2004). Antropología Política. Buenos Aires: Ediciones del Sol.

Bauzá, H. F (1998). El Mito del Héroe: morfología y semántica de la figura heroica. Buenos Aires, Fondo de Cultura Económica

Beck, U. (1998). La Invención de lo Político. México, Fondo de Cultural Económica.

Beck, U. (2006) La sociedad del Riesgo: hacia una nueva modernidad. Barcelona, Paidos.

Benjamín, W. (1982). "La Obra de arte en la época de su reproducción técnica". En Discursos Interrumpidos. Madrid, Ediciones Taurus.

Berger, P. (1971). El Dosel Sagrado. Buenos Aires, Amorrortu.

Bernstein, R. (2006). El Abuso del Mal. La corrupción de la Política y la Religión desde el 11 de Septiembre". Buenos Aires, Editorial Katz.

Blackmore, S. (2000). The Memes Machine. Oxford, Oxford University Press.

Carozzi, M. J (2005) "Revisando la Difunta Correa: nuevas perspectivas en el estudio de las canonizaciones populares en el Cono Sur de América". Revista de Investigaciones Folclóricas. Vol 20: 13-21.

Chesterton, G. K. (1997). Ortodoxia. México, Fondo de Cultura Económica.

Comaroff, J. and Comaroff, J. (1999). "Occult economies and the violence of abstraction". American Ethnologist 26(2):279-303.

Coulanges, F. de (2005) La ciudad Antigua. Madrid, Edaf.

Connolly, P (2006) Approaches to the Study of Religions. New York, The Continuum International publishing Group, pp.10-41.

Delgado, M (1993) "La religiosidad popular: en torno a un falso problema". Número 10 - Texto 10-08. Revista Digital Gazeta de Antropología. Universidad de Barcelona. Disponible en www.ugr.es. 
Durkheim, E. (1992) Las Formas elementales de la vida religiosa. Madrid, Akal.

Elías, N. (1998). La Civilización de los Padres y otros Ensayos. Bogotá, Editorial Norma.

Evans, M. (2003). "The Sacred: differentiating, Clarifying and Extending Concepts". Review of Religious Research. Volume 45. (1): 32-47. Brigham, Young University.

Fillipi, A. (1988). Instituciones e Ideologías en la Independencia Hispanoamericana. Buenos Aires: Alianza Editorial

Feuerbach, L. (2009). The Essence of Christianity. Madrid, Clasicos de la Cultura, Trotta Editorial.

Forster, R. (2009) Walter Benjamín: una introducción. Buenos Aires, Buenos Aires, Quadratta.

Foucault, M. (2006). Seguridad, Territorio, Población. Buenos Aires, Fondo de Cultura Económica.

Freud, S. (2004) Moisés y la Religión Monoteísta. Buenos Aires, Edición Losada.

Frigerio, A. (1999). "El futuro de las Religiones Mágicas en Latinoamérica". Ciencias Sociales y Religión. Año 1. Número 1. Pp: 51-88.

Gellner, D. N. (2006). "Anthropological Approaches". In Connolly, P Approaches to the Study of Religions. New York, The Continuum International publishing Group, pp.10-41.

Giddens, A. (1989). Sociología. Madrid, Editorial Alianza.

Hegel, G. W. F. (1992). Creer y Saber (cara y cruz). Bogotá, Norma.

Hobbes, T. (1998). Leviatán o la materia, forma y poder de una República Eclesiástica y Civil. México, Fondo de Cultura Económica.

Horowitz, I. L. (1984). "Religion, the State and Politics". In Aronoff, Myron. (Editor). Religion and Politics. New Brunswick, Transaction Books. Pp, 4-9.

Hungtinton, S. (1993). The Third Wave. Democratization in late Twentieth Century. Oklahoma, Oklahoma University Press.

Imaz, de J L. (1984). Sobre la Identidad Iberoamericana. Buenos Aires: Editorial Sudamericana.

Imaz, De J L. (1964) Los que Mandan. Buenos Aires, Eudeba. 
Jauretche, A. (1968). Manual de las Zonceras Argentinas. Buenos Aires, El corregidor.

Kierkegaard, S. (2003). Temor y Temblor. Buenos Aires, Losada.

Korstanje, M. (2007). "Procesos Políticos en América Latina: una perspectiva sobre la forma de ver la democracia de los latinoamericanos". Revista de Sociologia e Política. Vol. 29: 187-202

Korstanje, M. (2010a). "El Arquetipo Latino en la Construcción Española del Viaje durante la Conquista de América". Nómadas, Revista Crítica de Ciencias sociales y Jurídicas. Vol 27 (3): 141-172.

Korstanje, M. (2010b). "The Legacy of Samuel Huntington in Terrorist Studies after 9/11”. Cross Roads. Vol. 9 (2): 26-66.

Laclau, E. (2005). "Populismo: ¿Qué hay en el nombre?.". En Pensar este tiempo: espacios, afectos, pertenencias. Leonor Arfuch (Compiladora). Buenos Aires, Paidós, pp. 26-46.

Lasch, C. (2000). La Cultura del Narcisismo. Barcelona, Andrés Bello.

Lieuwen E. (1960) Armas y Política en América Latina. Buenos Aires, Editorial del Sur

Lorenzini, M. (2006) "Power a radical view". Reviewed in Crossroad. Vol. 6 (2): 87-95. Available at http://www.webasa.org/Pubblicazioni/Lorenzi_2006_2.pdf.

Lukes, S. (2005). Power a radical view. Basingstoke, Palgrave Macmillan.

Markale, J. (2006). Los Rebeldes de Dios. Buenos Aires, Ateneo.

Mouffe, C. (2005). "Políticas y Pasiones: las apuestas de la democracia". En Pensar este tiempo: espacios, afectos, pertenencias. Leonor Arfuch (Compiladora). Buenos Aires, Paidós, pp. 78-97.

Nietzsche, F. (2007). La Genealogía de la Moral. Buenos Aires, Gradifico.

Panettieri, J. (1970). Inmigración en la Argentina. Buenos Aires, Ediciones Macchi.

Pía-Lara, M. (2009). Narrar El Mal: una teoría post-metafísica del Juicio reflexionante. Barcelona, Editorial Gedisa.

Potash, R. A (1986). El Ejercito y La Política en la Argentina: 1928 - 1945 de Irigoyen a Perón. Buenos Aires, Editorial Hyspamerica

Robin, C. (2009). El Miedo: historia de una idea política. México, fondo de Cultural Económica 
Sarlo, B. (2011). Siete Ensayos sobre Walter Benjamín. Buenos Aires, Siglo $\mathrm{XXI}$

Semán, P (2001) "Cosmología, Holista y Relacional: una corriente de la religiosidad popular contemporánea. 2001". Ciencias Sociales y Religión, Vol 3: 45-74.

Smart, N. (1998). The World's religion. Cambridge, Cambridge University Press.

Soneira, E A et al. (1996). Sociología de la Religión. 1996 Buenos Aires, Docencia.

Soyinka, W. (2007). Clima de Miedo. Barcelona, Tusquets.

Veblen, T. (1974). La Clase Ociosa. México, Fondo de Cultura Económica.

Weber, M. (1987). Ensayos sobre la Sociología de la Religión. Madrid, Taurus.

Wolf, E. (2004). "Figura el poder: ideologías de dominación y crisis". Revista Reflexiones. Número 183.

Zizek, S. (1989). The Sublime Object of Ideology. New York, Verso.

Zizek, S. (2005). El Títere y el Enano: en núcleo perverso del Cristianismo. Buenos Aires, Paidos

Zizek, S. (2009a). Violence. Buenos Aires, Paidos.

Zizek, S. (2009b). The Monstrosity of Christ. MIT press. 